OPEN ACCESS

Edited by:

Jackson Cioni Bittencourt University of São Paulo, Brazil

Reviewed by:

Namas Chandra, New Jersey Institute of Technology,

United States

Abbas F. Sadikot,

McGill University, Canada

*Correspondence:

Fernanda Troili

f.troili86@gmail.com

Received: 30 September 2019 Accepted: 23 March 2020 Published: 16 April 2020

Citation:

Troili F, Cipollini V, Moci M, Morena E,

Palotai M, Rinaldi V, Romano C, Ristori G, Giubilei F, Salvetti M, Orzi F,

Guttmann CRG and Cavallari $M$ (2020) Perivascular Unit: This Must Be the Place. The Anatomical Crossroad

Between the Immune, Vascular and Nervous System.

Front. Neuroanat. 14:17.

doi: 10.3389/fnana.2020.00017

\section{Perivascular Unit: This Must Be the Place. The Anatomical Crossroad Between the Immune, Vascular and Nervous System}

\begin{abstract}
Fernanda Troili ${ }^{1 *}$, Virginia Cipollini ${ }^{1}$, Marco Moci ${ }^{2}$, Emanuele Morena ${ }^{3}$, Miklos Palotai ${ }^{4}$, Virginia Rinaldi ${ }^{3}$, Carmela Romano ${ }^{3}$, Giovanni Ristori ${ }^{5}$, Franco Giubilei ${ }^{6}$, Marco Salvetti ${ }^{5,7}$, Francesco Orzi ${ }^{3}$, Charles R. G. Guttmann ${ }^{4}$ and Michele Cavallari ${ }^{4}$

${ }^{1}$ Department of Human Neuroscience, Sapienza University of Rome, Rome, Italy, ${ }^{2}$ Department of Medicine, Surgery and Dentistry, "Scuola Medica Salernitana", Neuroscience Section, University of Salerno, Baronissi, Italy, ${ }^{3}$ Department of Neurology and Psychiatry, Sapienza University of Rome, Rome, Italy, ${ }^{4}$ Center for Neurological Imaging, Department of Radiology, Brigham and Women's Hospital, Harvard Medical School, Boston, MA, United States, ${ }^{5}$ Department of Neurosciences, Mental Health and Sensory Organs, Faculty of Medicine and Psychology, Centre for Experimental Neurological Therapies, Sapienza University, Rome, Italy, ${ }^{6}$ Department of Neurosciences Mental Health and Sensory Organs, Faculty of Medicine and Psychology, Sapienza University of Rome, Rome, Italy, ${ }^{7}$ IRCCS Istituto Neurologico Mediterraneo (INM) Neuromed, Pozzilli, Italy
\end{abstract}

Most neurological disorders seemingly have heterogenous pathogenesis, with overlapping contribution of neuronal, immune and vascular mechanisms of brain injury. The perivascular space in the brain represents a crossroad where those mechanisms interact, as well as a key anatomical component of the recently discovered glymphatic pathway, which is considered to play a crucial role in the clearance of brain waste linked to neurodegenerative diseases. The pathological interplay between neuronal, immune and vascular factors can create an environment that promotes self-perpetration of mechanisms of brain injury across different neurological diseases, including those that are primarily thought of as neurodegenerative, neuroinflammatory or cerebrovascular. Changes of the perivascular space can be monitored in humans in vivo using magnetic resonance imaging (MRI). In the context of glymphatic clearance, MRI-visible enlarged perivascular spaces (EPVS) are considered to reflect glymphatic stasis secondary to the perivascular accumulation of brain debris, although they may also represent an adaptive mechanism of the glymphatic system to clear them. EPVS are also established correlates of dementia and cerebral small vessel disease (SVD) and are considered to reflect brain inflammatory activity. In this review, we describe the "perivascular unit" as a key anatomical and functional substrate for the interaction between neuronal, immune and vascular mechanisms of brain injury, which are shared across different neurological diseases. We will describe the main anatomical, physiological and pathological features of the perivascular unit, highlight potential substrates for the interplay between different noxae and summarize MRI studies of EPVS in cerebrovascular, neuroinflammatory and neurodegenerative disorders.

Keywords: glymphatic system, perivascular space (PVS), neurodegenaration, neuroinflammation, amyloid, aquaporin (AQP)-4, blood brain barrier (BBB) 


\section{THE PERIVASCULAR UNIT}

\section{Overview}

We are adopting the term perivascular unit (PVU) in order to stress the contribution of cellular and molecular actors that surround the perforating vessels in the brain, and their interactions in determining the function the perivascular space (see Figure 1).

The perivascular space consists of a single or double layer of invaginated pia (Osborn and Preece, 2006), forming an interstitial fluid-filled space which represents the extension of the extracellular fluid space around the intracranial vessels as they dive into the brain parenchyma (Kwee and Kwee, 2007). The anatomy of perivascular spaces varies by location: in the centrum semiovale around superficial perforating arteries have only one layer of pia mater, while in the basal ganglia around the deep perforating arteries have two (Pollock et al., 1997).

Different factors have been associated with dynamic volume changes of the perivascular space, including vessel changes in diameter (vasoconstriction/vasodilation), neuronal activity, and neuronal and astrocytic swelling (Schain et al., 2017). A recent functional magnetic resonance imaging study (Fultz et al., 2019) suggests an alternation between blood and cerebrospinal fluid (CSF) flow during sleep, a condition known to be associated with glymphatic inflow of CSF through the perivascular space (Xie et al., 2013). Neural activity as measured by EEG preceded the CSF dynamics, thus suggesting that neural rhythms precede subsequent reduction in blood volume that allows CSF inflow through the perivascular space (Fultz et al., 2019).

\section{Cells of the PVU}

The cellular components of the perivascular unit are mainly represented by neurons, but also include cells with predominant immune and support functions, such as endothelial cells, microglia, and pericytes.

As the pial and deep penetrating (lenticulostriate) arteries dive into the brain parenchyma, they gain pericytes between the endothelial cells and astrocyte endfeet. Along the length of the vessel, endothelial cells, neurons, pericytes, and astrocytes are in close proximity and their interaction constitutes the cellular substrate of the PVU function.

Endothelial cells lining the cerebral blood vessels represent one of the critical layers of the blood-brain barrier (BBB), which controls access of cells and molecules to the brain parenchyma. Transcytosis is limited by the lack of fenestrae in the endothelial cell layer (Iadecola, 2004) and paracellular transport of ions, macromolecules and other solutes is restrained by a tight interendothelial seal, mainly provided by tight junctions (Hawkins et al., 2006; Presta et al., 2018) made of transmembrane proteins coupled to the cytoskeletal actin (Stamatovic et al., 2016). As a result, most immunocompetent cells cannot access the brain parenchyma under physiological conditions, a phenomenon known as immune privilege.

The only exception is represented by the microglia, the resident brain macrophages that provide immuno-surveillance and first line defense against pathogens (Hickey and Kimura, 1988). During development, the microglia shape neural networks through synaptic pruning (Hong et al., 2016) and promote angiogenesis through interaction with endothelial progenitors (Engelhardt and Liebner, 2014). Microglial cells have small cell bodies and numerous long branching processes to survey the surrounding microenvironment for immune surveillance. Microglial cells are abundant in the surroundings of blood vessels and can be activated by pathogens and paracrine soluble factors released by activated monocytes and lymphocytes, as well as by the activated microglia themselves. When activated, the microglial cells change their morphology to larger nuclei and shorter processes, secrete numerous cytokines and soluble factors, and become highly phagocytic (Dudvarski Stankovic et al., 2016). Although the activated state of microglia is often referred to as a polarized phenotype-either pro- or antiinflammatory - the spectrum of microglial states in response to pathogens and inflammatory stimuli appears to be much diverse than this dichotomous model would suggest (Mosser and Edwards, 2008). Activated microglia also release cytokines and chemokines that may result in increased BBB permeability and allow the migration of immune cells from the periphery into the central nervous system (CNS) (da Fonseca et al., 2014; Goldmann T. et al., 2016). Although the role of the microglia in neurological diseases is not completely understood, it can be summarized in two phenomena: one beneficial, with microglia acting as housekeeping phagocytes to maintain tissue homeostasis; another one harmful, with the microglia determining a pro-inflammatory state that results in synaptic dysfunction and increased secretion of potentially neurotoxic cytokines. Interestingly, both clinical and animal model studies revealed that microglial activation may occur at early stages of neurodegenerative, cerebrovascular, and neuroinflammatory diseases, such as Alzheimer's disease (AD), vascular dementia, and multiple sclerosis (MS) (Matsumoto et al., 1992; Wakita et al., 1994; Ihara et al., 2001; Ponomarev et al., 2005).

The resident microglia are part of the larger neuroglial cellular system, which includes non-neuronal cells of the nervous system, including astrocytes, oligodendrocytes, and pericytes. Those cells not only provide structural support to the brain parenchyma, but also respond to injury, regulate the ionic and chemical composition of the extracellular milieu, form the myelin insulation of the brain wiring, guide neuronal migration during development, and exchange metabolites with neurons (Verkhratsky and Steinhäuser, 2000).

Astrocytes constitute the physical bounding, with their endfoot processes, of the capillaries in the perivascular space. They extend their end-feet to the surface of cerebral blood vessels, providing 99\% abluminal vessel coverage (Sosunov et al., 2014; Filosa et al., 2016). This position allows them to regulate cerebral blood flow in dynamic response to synaptic activity and neuronal metabolism (McConnell et al., 2017). Astrocytes can release vasoactive substances in response to neural activation, which adjust regional cerebral blood flow to provide an adequate supply of oxygen and nutrients to maintain the brain structural and functional integrity (Muoio et al., 2014). Astrocytes are also implicated in the glymphatic clearance of interstitial solutes linked to neurodegenerative processes, such as beta-amyloid and tau proteins. The trans-membrane water channel aquaporin- 4 


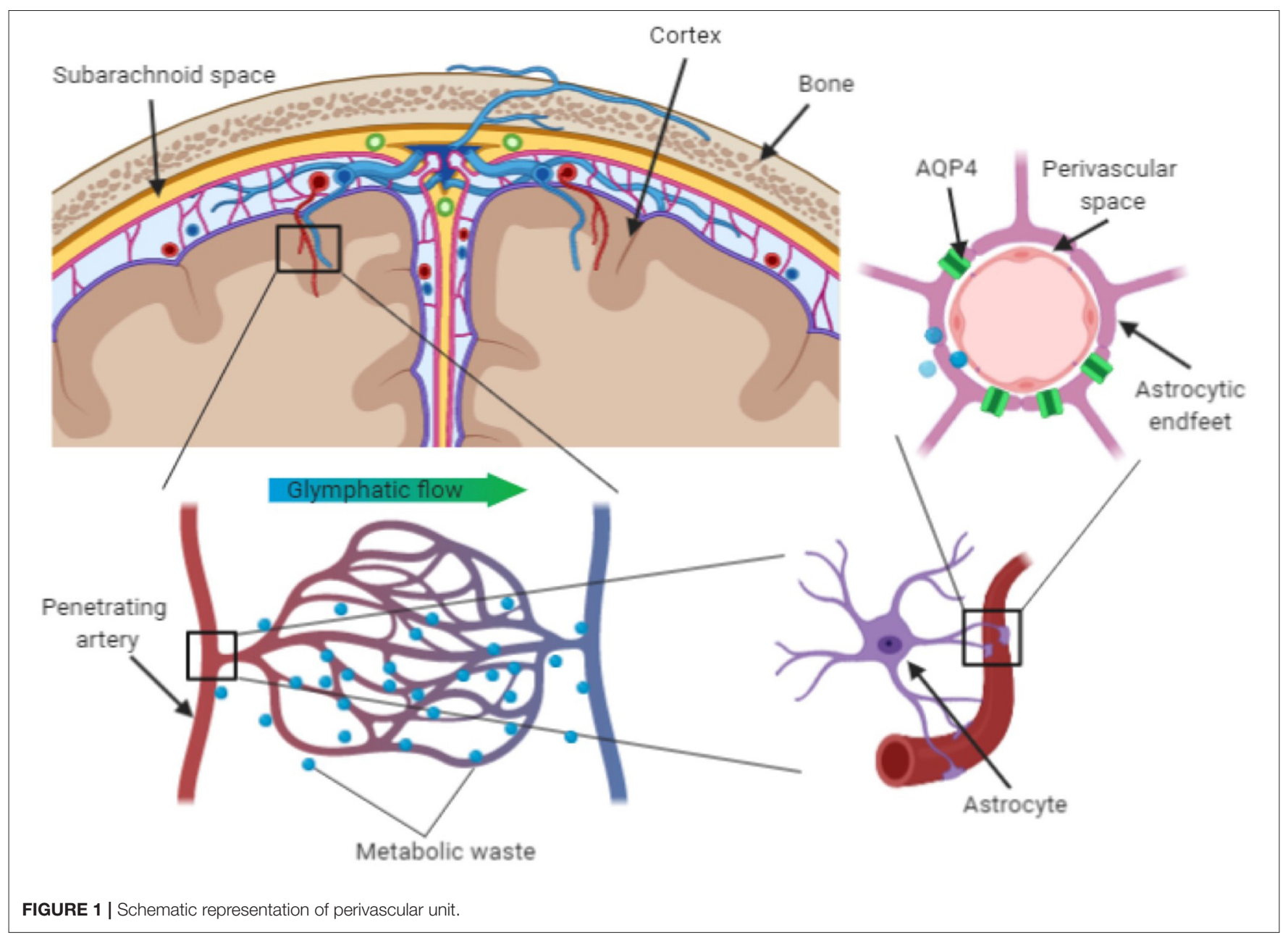

(AQP4) in particular plays a crucial role. Up to $50 \%$ of the brain aquaporin-4 (AQP4) is expressed on the astrocytes' endfeet and its density is higher in regions lining the cerebral ventricles (Jessen et al., 2015; Trevaskis et al., 2015; Plog and Nedergaard, 2018). Since AQP4 facilitates fluid exchanges between inflowing CSF and interstitial fluid, it is considered to play a key role in the clearance of potentially neurotoxic metabolites that accumulate in the interstitial space (Keep and Jones, 1990).

Experimental evidence supports that astrocytes promote myelination, as well as re-myelination after myelin injury (Domingues, 2016). During development, quiescent astrocytes may potentiate or prevent the differentiation of oligodendrocyte progenitor cells into mature myelinating oligodendrocytes. Astrocytes also contribute to the maintenance of myelin by stimulating myelin production in myelinating oligodendrocytes. In response to demyelinating injury, astrocytes secrete chemokines (e.g. CCL2 and CXCL10) to recruit activated microglia, which may further contribute to myelin injury (Moyon S Dubessy et al., 2015). Astrocytes and microglia can also promote remyelination after myelin injury, for instance by secreting chemokines (e.g. CXCL1, CXCL8 and CXCL10) to recruit oligodendrocyte progenitor cells to repopulate demyelinated regions (Omari et al., 2005).
Oligodendrocytes are best known for their role in forming the myelin sheets around neuronal axons that enable the saltatory conduction of neural signals across the cerebral white matter (Hamanaka et al., 2018). Oligodendrocytes also release growth factors for neighboring cells, as well as angiogenic factors associated with oligodendrogenesis of the adult white matter. Oligodendrocytes interact with other cells of the PVU, including pericytes, astrocytes and microglia. Their interaction with perycites is crucial for the development of the cerebral cortex and blood vessels (Choe et al., 2014; Uemura et al., 2018). The interaction between oligodendrocytes and microglia is crucial for myelination during brain development, as well as remyelination in demyelinating diseases, such as MS. One critical function of microglia in response to demyelination is the phagocytosis of myelin debris that would otherwise interfere with the recruitment and differentiation of oligodendrocyte progenitor cells (Kotter et al., 2006; Miron, 2017).

Pericytes are multifunctional mural cells wrapped around endothelial cells that line capillaries and venules. They are embedded in the basement membrane and communicate with endothelial cells by means of direct physical contact and paracrine signaling. Pericytes regulate capillary blood flow, the clearance and phagocytosis of cellular debris, and 
permeability of the blood-brain barrier (Wilhelm et al., 2016). Endothelial cells and pericytes are interdependent. The crosstalk between endothelial cells and pericytes is crucial for pericyte differentiation, recruitment and migration, but also for the maturation and stabilization of endothelial cells (Armulik et al., 2005). Communication failure between these two cell types is associated with several pathological conditions, including cardioand cerebrovascular diseases, neurodegenerative diseases, and diabetic retinopathy. The platelet-derived growth factor signaling pathway of endothelial cells plays a key role in the crosstalk between pericytes and endothelial cells. Inhibition of this signaling pathway results in pericyte deficiency and endothelial hyperplasia, and is associated with diabetic retinopathy (Hammes et al., 2002).

\section{PVU and Glymphatic Clearance}

The perivascular space has recently regained attention following the breakthrough discovery of the glymphatic pathway of clearance, of which the perivascular space is a crucial node (Xie et al., 2013). The glymphatic (glia + lymphatic) pathway of clearance has been named after the key role of glial cells and similarities with the lymphatic system (Nielsen et al., 1997; Nedergaard, 2013). Potentially neurotoxic soluble waste products are continuously released in the interstitial space due to the brain's high metabolic rate (Louveau et al., 2018) and the glymphatic pathway is considered a major route for the drainage of those metabolites.

Studies in animal models suggest that bulk flow of CSF enters the brain through the periarterial space and drains soluble waste products that accumulate in the interstitial space through the perivenous space to the subarachnoid space. From the subarachnoid space, those products are eliminated through the meningeal lymphatics to the extracranial lymphatic system (Tarasoff-Conway et al., 2015; Louveau et al., 2018). This mechanisms has been first described in rodents during sleep, when an observed $60 \%$ enlargement of the interstitial space associated with increased inflow of CSF through the perivascular space resulted in two times faster clearance of beta-amyloid (Xie et al., 2013), a protein implicated in the pathogenesis of AD. Although different mechanisms of beta-amyloid clearance have been demonstrated (including enzymatic degradation and cellular uptake, and transport across the blood-brain barrier), it has been estimated that $55-65 \%$ of the total extracellular betaamyloid is eliminated through the glymphatic pathway (TarasoffConway et al., 2015).

Hypothetically, a similar case may be made for soluble phase alpha-synuclein species in the brain but remains unproven at the present time. Given that patients with neurodegenerative disorders such as $\mathrm{AD}$ and Parkinson' disease (PD) have well-documented sleep disorders, it is not unreasonable to speculate that the sleep disturbances place an additional burden on an already dysfunctional protein folding and degradation system. Abnormal levels of alpha-synuclein are common to several neurodegenerative diseases (e.g., Lewy body disease, multiple system atrophy, PD), suggesting that aggregation of this protein is particularly neurotoxic and exacerbates neuronal degeneration (Yang et al., 2018; Parnetti et al., 2019). Though alpha-synuclein conformation change and accumulation were traditionally thought to occur in the neuron itself, recent evidence supports that alpha-synuclein is excreted into extracellular spaces (Emmanouilidou et al., 2011), making the neuropathological underpinnings of CSF-ISF flow in the pathogenesis of neurodegenerative disease processes is of high interest.

This led to some authors (Sundaram et al., 2019) proposing that glymphatic flow may be compromised due to the combined neurotoxic effects of alpha-synuclein protein aggregates and deteriorated dopaminergic neurons that are linked to altered REM sleep, circadian rhythms, and clock gene dysfunction (Gjerstad MD et al., 2008; Cai et al., 2010; Breen et al., 2014). Nevertheless, the observation that anesthesia increases glymphatic influx and efflux (Xie et al., 2013), suggests that it is not circadian rhythm but rather the sleep-wake state itself that determines the volume of the interstitial space and therefore the efficiency of glymphatic solute clearance. In this context, locus coeruleus-derived adrenergic signaling in the awake state seems to modify cell volume and thus the size of the interstitial space.

The glymphatic pathway has been best characterized in animal models. Studies investigating the glymphatic mechanism of clearance in humans are very limited. However, preliminary findings support the presence of a similar mechanism of clearance in humans. A small positron emission tomography study showed reduced beta-amyloid clearance through the cerebrospinal fluid in $8 \mathrm{AD}$ patients compared to 7 healthy controls, as well as an association between brain deposition of beta-amyloid and reduced clearance (de Leon et al., 2017). An association between beta-amyloid deposition and reduced CSF turnover has been described in 20 subjects with normal pressure hydrocephalus (de Leon et al., 2017). Reduced beta-amyloid clearance through the CSF was also described in a small study of $8 \mathrm{AD}$ patients (Ringstad et al., 2017). A functional MRI study showed large-amplitude pulsatile flow of CSF associated with non-REM sleep, possibly reflecting CSF dynamics associated with the glymphatic mechanisms of clearance described in animal models (Fultz et al., 2019).

\section{THE PVU IN NEUROLOGICAL DISEASES}

The etiology of most neurological diseases is unknown, and they are often described as multifactorial. The search for a primum movens - neuronal, vascular or immune-mediated-has been long considered critical to identify "the mechanism" to be targeted by early therapeutic interventions aimed at effectively contrasting the development and progression of the disease. However, remarkable overlapping of those mechanisms of brain injury at very early stages of disease pathogenesis has been demonstrated in many neurological diseases. A prototypical example regards the pathogenesis of $\mathrm{AD}$, which was initially considered of vascular origin based on histopathological evidence of beta-amyloid deposits in the vessel wall (Sweeney, 2018). Over the course of the last century, different hypotheses of $\mathrm{AD}$ pathogenesis have emerged. Evidence of neurodegenerative processes associated with the progression of the disease 
contributed to ascribe the disease to a primarily neuronal etiology, as opposed to the initial vascular hypothesis. The etiology of $\mathrm{AD}$ is currently still debated and the overlapping contribution of vascular, neurodegenerative, and inflammatory mechanisms of brain injury from the very early stage has emerged as a key feature of AD pathogenesis (Iadecola and Gorelick, 2003). Another example is the emerging role of vascular factors in the formation of MS lesions-a disease that is considered primarily immune-mediated (Spencer et al., 2018).

The PVU represents a crossroad for the interaction of neurodegenerative, vascular, and immune mechanisms of brain injury. Here we describe those overlapping mechanisms, with particular focus on the cross-link between glymphatic, vascular and immune mechanisms potentially leading to neurodegenerative processes. A better understanding of the interaction between those mechanisms may lead to novel therapeutic approaches targeting combined factors, which may arguably be more effective in contrasting the development and progression of neurological diseases.

\section{Glymphatic Dysfunction}

The glymphatic pathway has emerged as a key mechanism of clearance of $\mathrm{A} \beta$ and tau proteins (Iliff et al., 2012; Xie et al., 2013), the two hallmarks of AD pathobiology. According to the amyloid cascade hypothesis (Hardy and Higgins, 1992), the deposition of $A \beta$ in the form of plaques is considered an early event in the pathogenesis of AD. Since a remarkable amount of $\mathrm{A} \beta$ is eliminated through the glymphatic pathway (Iliff et al., 2012, 2013; Xie et al., 2013), impaired glymphatic clearance could be implicated in the development and progression of $\mathrm{AD}$. Interestingly, $\mathrm{A} \beta$ has detrimental effect on the glymphatic clearance, thus potentially leading to a deleterious feedback loop toward further impaired drainage and neurodegeneration (Carare et al., 2008; Iliff et al., 2012).

\section{Relationship Between Glymphatic and Vascular Abnormalities}

Glymphatic dysfunction may be further impaired by vascular factors, including arteriosclerosis, vascular tortuosity, reduction in smooth muscle cell efficiency, and $\mathrm{A} \beta$ deposition in the vessel wall (Kalaria, 2002; Thore et al., 2007; Hawkes et al., 2011; Arbel-Ornath et al., 2013; Weller et al., 2015). Damage to the brain vasculature can lead to loss of perivascular integrity and AQP4 polarization (Iliff et al., 2012), as well as impairment of cerebrovascular pulsatility (Hadaczek et al., 2006), which is believed to facilitate CSF flow through the perivascular space. In older individuals, insoluble fibrillar $\mathrm{A} \beta$ deposits in the basement membranes of the walls of cerebral capillaries and arteries with the same spatial distribution of the perivascular pathways outlined by the injection of fluorescent tracers in the mouse brain (Weller et al., 2008). The initial deposition and subsequent accumulation of $A \beta$ occurs in the lamina densa in the center of basement membranes surrounding smooth muscle cells in the artery wall. This may further disrupt perivascular drainage and thus exacerbate the impaired clearance of $A \beta$ and other soluble waste from the aging brain (Hawkes et al., 2011, 2013).

\section{Vascular Abnormalities, Blood-Brain Barrier Permeability and Neuroinflammation}

Pericytes and endothelial cells have a key structural role within the PVU. In animal models with lower pericyte coverage it has been observed an increased traffic of molecules across endothelial cells, which may enable proteins that would not have access to the brain in physiological conditions to enter the brain and potentially trigger an inflammatory response (Armulik et al., 2010). In a histopathological study of patients with $\mathrm{AD}$, a significant loss of pericytes associated with $\mathrm{BBB}$ leakage was observed in the hippocampus and frontal cortex (Sengillo et al., 2013). In mice with AD-like pathology, loss of pericytes was observed in both the cortex and the hippocampus, while progressive perivascular dissociation of pericytes was characteristic to the hippocampus (Janota et al., 2015). Interestingly, pericytes have been described to migrate form the vessel wall during several pathological conditions (e.g., tumors, diabetic microangiopathy) (Ferland-McCollough et al., 2017). Although the pathogenic significance of pericyte dropout from the vessel wall is currently unknown, it has been hypothesized that this phenomenon is linked to increased endothelial and BBB permeability (Armulik et al., 2010).

In pathological conditions associated with increased $\mathrm{BBB}$ permeability, including neurodegenerative (e.g., AD), vascular (e.g., small vessel disease) and neuroinflammatory diseases (e.g., MS), T cells may enter the brain and encounter activated antigen presenting cells (Engelhardt et al., 2016), which are strategically localized in the perivascular space (Greter et al., 2005). Antigen presenting cells can induce proliferation and differentiation of encephalitogenic $\mathrm{T}$ cells, which release pro-inflammatory cytokines and trigger parenchymal invasion of other immune cells (Kawakami et al., 2004). This is well-established in EAE models where the recognition of the antigen expressed on antigen presenting cells is a fundamental prerequisite for the migration into the CNS of CD4+ T cells that trigger immune-mediated injury responsible for the clinical manifestations of the disease (Engelhardt et al., 2016).

\section{Relationship Between Glymphatic and Immune-Mediated Mechanisms of Brain Injury}

The glymphatic clearance is tightly linked to the lymphatic system, in addition to the brain vasculature and perivascular space. The negative pressure that allows glymphatic flow is considered to derive from the meningeal lymphatics, which adsorb the subarachnoid CSF and drive soluble brain waste to the extra-cranial lymph nodes (Kipnis, 2016). The perivascularlymphatic pathway represents the main route for drainage of antigens from the brain to cervical lymph nodes (Engelhardt and Coisne, 2011), with implications for immune tolerance and autoimmunity (Wolvers et al., 1999; Furtado et al., 2008; van Zwam et al., 2009). Specialized antigen presenting cells, such as macrophages, dendritic cells and $\mathrm{T}$ cells, are abundant in the leptomeninges and perivascular space, and they travel to the deep cervical lymph nodes through the same route of CSF flow, 
under both physiological and pathological conditions (Louveau et al., 2018). Several studies showed presence of $\mathrm{T}$ cells, antigen presenting cells and myelin and axonal antigens in cervical lymph nodes, after axonal injuries or autoimmune demyelination (de Vos et al., 2002; Fabriek et al., 2005; Goldmann J. et al., 2006; Hatterer et al., 2006; Engelhardt et al., 2016). In experimental autoimmune encephalomyelitis models (EAE, an animal model of MS) it has been shown that surgical or pharmacological blockage of lymphatic functions results in an attenuation of the disease (Louveau et al., 2018).

We have previously discussed how astrocytic AQP4 has a central role in the glymphatic mechanism of clearance of brain waste by facilitating water exchanges between the CSF and interstitial fluid. The role of AQP4 in neuroinflammatory conditions potentially linked to impaired glymphatic clearance has been investigated in EAE, as well as neuromyelitis optica (NMO), an inflammatory disease characterized by autoantibodies against AQP4 resulting primarily in complement-dependent astrocyte injury and secondarily in neuroinflammation, demyelination, and neuronal loss. AntiAQP4 antibodies appear to alter the immunoregulatory function and barrier capacity of astrocytes (Hirt et al., 2018). In EAE, a loss of perivascular AQP4 localization has been reported (WolburgBuchholz et al., 2009). It is conceivable that impaired AQP4 function, due to either auto-antibodies (NMO) or mislocalization (EAE), may exert a deleterious effect on the glymphatic clearance, which ultimately contributes to the accumulation of neurotoxic solutes that may lead to neurodegeneration (Simon and Iliff, 2016; Plog and Nedergaard, 2018).

Furthermore, dopamine has been shown to reduce the proliferation of striatal glial cells and their expression of AQP4 (Küppers et al., 2008). Additionally, AQP-4 deficiency has been associated with enhanced susceptibility to insult of the dopaminergic neurons between the substantia nigra and ventral tegmental area (Zhang et al., 2016). Therefore, as dopaminergic neurons appear to modulate AQP4 function and AQP4 deficiency can exacerbate dopaminergic neuronal loss, the interplay of both processes may be impairing glymphatic system functioning and subsequently result in suboptimal clearance of alpha-synuclein in Parkinson's disease (PD).

The relationship between glymphatic dysfunction and inflammation has been studied in $\mathrm{AD}$, a condition characterized by the brain deposition of $A \beta$ in the form of plaques and tau proteins in the form of neurofibrillary tangles. Both $A \beta$ and tau are eliminated through the glymphatic pathway, and their deposition in the brain is associated with synaptic dysfunction and neuronal loss. $A \beta$ plaques and neurofibrillary tangles for their part can also trigger a secondary inflammatory response that may exacerbate neurodegeneration. Reactive astrogliosis and microglial activation surrounding amyloid plaques are established histopathological features of AD (Barger and Harmon, 1997). A $\beta$ activates astrocytes and microglial cells through Toll-like receptor 4 (Reed-Geaghan et al., 2009). Activated astrocytes facilitate $A \beta$ elimination across the BBB by low-density lipoprotein receptor-related protein 1 (Koistinaho et al., 2004), but excessive uptake of $\mathrm{A} \beta$ results in astrocyte dysfunction and apoptosis, leading to decreased clearance and increased accumulation of $\mathrm{A} \beta$ (Blanco et al., 2010). Interestingly, astrocyte activation is modulated by astrocytic AQP4, a protein that has a key role in the glymphatic mechanism of clearance. This further supports the link between glymphatic and immunemediated mechanisms of brain injury and repair. Genetic ablation of AQP4 reduces the A $\beta$-induced activation of cultured astrocytes, leading to a reduction in the cellular uptake of $\mathrm{A} \beta$ and therefore contributing to worsen $\mathrm{A} \beta$ pathology (Yang et al., 2012). Activated microglia proliferate and overexpress genes coding for proinflammatory, potentially neurotoxic cytokines and receptors. Interestingly, studies in animal models showed that APO-E and TREM-2, two proteins implicated in determining the risk of cerebrovascular and neurodegenerative diseases, mediate the transition to neurodegeneration-like transcription profile in microglial cells (Krasemann et al., 2017). This further supports the overlap between neurodegenerative, cerebrovascular, and neuroinflammatory mechanisms of brain injury.

\section{IMAGING THE PVU IN HUMANS}

Although currently several efforts are underway to develop novel neuroimaging tools that may enable direct assessment of the glymphatic pathway of clearance (Ringstad et al., 2017; Eide et al., 2018), established methods to assess glymphatic flow in humans are not yet available. The perivascular space is a crucial node of the glymphatic pathway, and EPVS on MRI have recently emerged as biomarker of the pathway (Ramirez et al., 2016; Mestre et al., 2017). EPVS have been traditionally considered MRI correlates of small vessel disease (Wardlaw et al., 2013), have been shown to be associated with AD and small vessel disease in cross-sectional studies (Zhu et al., 2010; Wardlaw et al., 2013; Ramirez et al., 2015), and only recently have been proposed as MRI biomarker of the glymphatic pathway (Ramirez et al., 2016; Mestre et al., 2017). Based on the evidence of an association of EPVS with AD and small vessel disease, it has been speculated that EPVS may reflect glymphatic dysfunction or stasis. However, it remains unclear whether EPVS reflect glymphatic stasis or rather increased capacity of the perivascular space to drain potentially neurotoxic metabolites. To date, only one cross-sectional study examined the association between EPVS and brain deposition of beta-amyloid as measured by PET in $45 \mathrm{MCI}$ and 69 sporadic AD subjects and found no association between EPVS and amyloid load (Banerjee et al., 2017). Longitudinal studies are warranted to clarify the temporal dynamics of EPVS in AD, and their relationship with biomarkers of amyloid and tau pathology over the course of the disease.

EPVS can be detected using conventional MRI sequences (such as T1 and T2-weighted pulse sequences) that are usually employed in clinical practice to diagnose and monitor neurological diseases. According to the STandards for Reporting Vascular Changes on NEuroimaging (STRIVE) criteria (Wardlaw et al., 2013), MRI-visible EPVS appear as fluid-filled spaces that follow the course of penetrating vessels as they enter the brain parenchyma. They appear as slit-like, round or ovoid structures, 
TABLE 1 | Clinical and MRI correlates of perivascular spaces in previous structural neuroimaging studies on patients with Alzheimer's Disease.

\begin{tabular}{|c|c|c|c|c|c|c|c|c|c|}
\hline & $\begin{array}{l}\text { Patankar et al. } \\
(2005)\end{array}$ & Chen et al. (2011) & $\begin{array}{l}\text { Martinez- } \\
\text { Ramirez et al. } \\
\text { (2013) }\end{array}$ & $\begin{array}{l}\text { Hansen et al. } \\
\text { (2015) }\end{array}$ & $\begin{array}{l}\text { Ramirez et al. } \\
(2015)\end{array}$ & $\begin{array}{l}\text { Banerjee et al. } \\
(2017)\end{array}$ & Ding et al. (2017) & Shams et al. (2017) & $\begin{array}{l}\text { Banerjee et al. } \\
(2018)\end{array}$ \\
\hline $\begin{array}{l}\text { Number of } \\
\text { subjects } \\
\text { (Number of } \\
\text { females) }\end{array}$ & $\begin{array}{l}\text { AD: } 35(17) \\
\text { FTD: } 16(6) \\
\text { VaD: } 24(10) \\
\text { HC: } 35(24)\end{array}$ & $\begin{array}{l}\text { AD: } 37(23) \\
\text { MCl: } 71(26) \\
\text { HC: } 50 \text { (32) }\end{array}$ & $\begin{array}{l}\text { AD: } 37 \\
\text { CIND: } 52\end{array}$ & $\begin{array}{l}\text { AD: } 47(\mathrm{~N} / \mathrm{A}) \\
\text { VaD: } 39(\mathrm{~N} / \mathrm{A}) \\
\text { HC: } 65(\mathrm{~N} / \mathrm{A})\end{array}$ & $\begin{array}{l}\text { AD: } 203 \text { (108) } \\
\text { HC: } 94 \text { (53) }\end{array}$ & $\begin{array}{l}\text { AD: } 110(61) \\
\text { VaD: } 116(67)\end{array}$ & HC: 2612 (1542) \#\# & $\begin{array}{l}\text { AD: } 423(\mathrm{~N} / \mathrm{A}) \\
\text { MCl: } 418(\mathrm{~N} / \mathrm{A}) \\
\text { VaD: } 54(\mathrm{~N} / \mathrm{A}) \\
\text { CAA: } 98(\mathrm{~N} / \mathrm{A}) \\
\text { SCl: } 385(\mathrm{~N} / \mathrm{A})\end{array}$ & $\begin{array}{l}\text { AD: } 69 \text { (N/A) } \\
\text { aMCl: } 45 \text { (N/A) } \\
\text { VaD: } 70 \text { (N/A) } \\
\text { svMCl: } 67 \text { (N/A) }\end{array}$ \\
\hline $\begin{array}{l}\text { Age }(\text { mean } \pm \\
\text { SD, year) }\end{array}$ & $\begin{array}{l}\text { AD: } 61.6 \pm 7.01 \\
\text { FTD: } 63.2 \pm 9.24 \\
\text { VaD: } 64.5 \pm 7.35 \\
\text { HC: } 72.8 \pm 6.56\end{array}$ & $\begin{array}{l}\text { AD: } 74.6 \pm 9.0 \\
\text { MCl: } 74.8 \pm 7.6 \\
\text { HC: } 75.5 \pm 5.0\end{array}$ & $\begin{array}{l}\text { Mean age of } \\
\text { participants: } 72.7 \\
\pm 9.9^{\#}\end{array}$ & $\begin{array}{l}\text { AD: } 74.1 \pm 8.5 \\
\text { VaD: } 76.9 \pm 7.7 \\
\mathrm{HC}: 78 \pm 5.6\end{array}$ & $\begin{array}{l}\text { AD: } 72.7 \pm 8.8 \\
H C: 69.5 \pm 7.8\end{array}$ & $\begin{array}{l}\text { AD: } 70.3 \pm 8.8 \\
\text { VaD: } 73.8 \pm 7.0\end{array}$ & $74.6 \pm 4.8$ & $N / A^{\# \# \#}$ & $\begin{array}{l}\text { Mean age of } \\
\text { participants: } 72.2 \pm \\
8.1^{\# \# \# \#}\end{array}$ \\
\hline MRI scanner & $1.5 \mathrm{~T}$ & $3 T$ & 3Т & $1.5 \mathrm{~T}$ & $1.5 \mathrm{~T}$ & 3T & $1.5 \mathrm{~T}$ & $1.5 \mathrm{~T}-3 \mathrm{~T}$ & 3Т \\
\hline $\begin{array}{l}\text { EPVS } \\
\text { quantification }\end{array}$ & $\begin{array}{l}\text { Manual EPVS count } \\
\text { in frontal, parietal, } \\
\text { and occipital } \\
\text { periventricular } \\
\text { regions; deep WM; } \\
\text { BG and brainstem) }\end{array}$ & $\begin{array}{l}\text { Manual EPVS } \\
\text { scoring in } 8 \text { brain } \\
\text { regions, including } \\
\text { structures in the WM } \\
\text { (subregions of the } \\
\text { frontal lobe, } \\
\text { temporal lobe, } \\
\text { parietal lobe, } \\
\text { occipital lobe, and } \\
\text { the CS), BG, } \\
\text { brainstem and } \\
\text { hippocampal area }\end{array}$ & $\begin{array}{l}\text { Established } \\
\text { 4-point } \\
\text { semiquantitative } \\
\text { score in BG and } \\
\text { WM }\end{array}$ & $\begin{array}{l}\text { Semiquantitative } \\
\text { EPVS scoring } \\
\text { systems }\end{array}$ & $\begin{array}{l}\text { Semiquantitative } \\
\text { assessment of EPVS } \\
\text { in BG and CS }\end{array}$ & $\begin{array}{l}\text { Manual EPVS count } \\
\text { in BG and CS }\end{array}$ & Visual rating & $\begin{array}{l}\text { Visual rating in the CS } \\
\text { and } B G \text { of EPVS }\end{array}$ & $\begin{array}{l}\text { Visual rating in basal } \\
\text { ganglia }\end{array}$ \\
\hline $\begin{array}{l}\text { Association of } \\
\text { EPVS with AD }\end{array}$ & $\begin{array}{l}\text { EPVS scores in both } \\
\text { the BG and the CS } \\
\text { were significantly } \\
\text { higher in those with } \\
\text { VaD than in } \\
\text { patients with AD } \\
\text { EPVS in the CS } \\
\text { were } \\
\text { significantly more } \\
\text { frequent in patients } \\
\text { with FTD than } \\
\text { in HC. }\end{array}$ & $\begin{array}{l}\text { Greater levels of } \\
\text { EPVS in } \mathrm{AD} \text { and } \mathrm{MCl} \\
\text { compared to } \mathrm{HC}\end{array}$ & $\begin{array}{l}\text { No apparent } \\
\text { difference } \\
\text { between the two } \\
\text { groups }\end{array}$ & $\begin{array}{l}\text { PVS dilation } \\
\text { demonstrates } \\
\text { greater specificity for } \\
\text { discrimination } \\
\text { among VaD, } A D \text {, } \\
\text { and healthy } \\
\text { individuals than } \\
\text { white matter } \\
\text { scoring schemes. }\end{array}$ & $\begin{array}{l}\text { AD patients have } \\
\text { significantly greater } \\
\text { volumes of EPVS in } \\
\text { the WM }\end{array}$ & $\begin{array}{l}\text { Significantly higher } \\
\text { CS EPVS count in } \\
\text { clinically diagnosed } \\
\text { AD and higher BG } \\
\text { EPVS in clinically } \\
\text { diagnosed VaD } \\
\text { No association with } \\
\text { PiB PET positivity. }\end{array}$ & $\begin{array}{l}\text { Association with an } \\
\text { increased risk of } \\
\text { developing VaD but } \\
\text { not with all-cause } \\
\text { dementia or AD }\end{array}$ & $\begin{array}{l}\text { BG-EPVS showed to } \\
\text { be associated with } \\
\text { high CSF tau in the } \\
\text { whole cohort and in } \\
\text { AD } \\
\text { BG-EPVS was } \\
\text { associated with VaD. }\end{array}$ & $\begin{array}{l}\text { Presence of }>10 \\
\text { BG-EPVS was } \\
\text { included as an item of } \\
\text { a SVD score, which } \\
\text { was associated with } \\
\text { deficits in frontal and } \\
\text { visuospatial } \\
\text { performance (across } \\
\text { all participants) }\end{array}$ \\
\hline $\begin{array}{l}\text { Association of } \\
\text { EPVS with } \\
\text { clinical or } \\
\text { demographic } \\
\text { variables }\end{array}$ & $\mathrm{N} / \mathrm{A}$ & $\begin{array}{l}\text { Significant } \\
\text { association with } \\
\text { advanced age }\end{array}$ & $\begin{array}{l}\text { Association of } \\
\text { BG-EPVS with } \\
\text { hypertension in } \\
\text { patients with } \\
\text { cognitive } \\
\text { impairment }\end{array}$ & $\mathrm{N} / \mathrm{A}$ & $\begin{array}{l}\text { Greater volumes of } \\
\text { total EPVS in men }\end{array}$ & N/A & & $\begin{array}{l}\text { CS- and BG-PVS } \\
\text { were both associated } \\
\text { with high age and } \\
\text { hypertension }\end{array}$ & N/A \\
\hline
\end{tabular}


TABLE 1 | Continued

\begin{tabular}{|c|c|c|c|c|c|c|c|c|c|}
\hline & $\begin{array}{l}\text { Patankar et al. } \\
(2005)\end{array}$ & Chen et al. (2011) & $\begin{array}{l}\text { Martinez- } \\
\text { Ramirez et al. } \\
\text { (2013) }\end{array}$ & $\begin{array}{l}\text { Hansen et al. } \\
(2015)\end{array}$ & $\begin{array}{l}\text { Ramirez et al. } \\
\text { (2015) }\end{array}$ & $\begin{array}{l}\text { Banerjee et al. } \\
\text { (2017) }\end{array}$ & Ding et al. (2017) & Shams et al. (2017) & $\begin{array}{l}\text { Banerjee et al. } \\
(2018)\end{array}$ \\
\hline $\begin{array}{l}\text { Association of } \\
\text { EPVS with } \\
\text { brain MRI } \\
\text { variables }\end{array}$ & $\begin{array}{l}\text { CS EPVS score } \\
\text { positively correlated } \\
\text { with atrophy in } \\
\text { patients with FTD } \\
\text { and VaD }\end{array}$ & $\begin{array}{l}\text { Association of EPVS } \\
\text { total score with } \\
\text { leukoaraiosis and } \\
\text { atrophy }\end{array}$ & $\begin{array}{l}\text { Associations of } \\
\text { WM-EPVS with } \\
\text { lobar microbleeds } \\
\text { in patients with } \\
\text { cognitive } \\
\text { impairment }\end{array}$ & $\mathrm{N} / \mathrm{A}$ & $\mathrm{N} / \mathrm{A}$ & $\mathrm{N} / \mathrm{A}$ & $\begin{array}{l}\text { Association of EPVS } \\
\text { with increased risk } \\
\text { of incident } \\
\text { subcortical infarcts } \\
\text { and microbleeds } \\
\text { and greater WM } \\
\text { hyperintensities } \\
\text { progression }\end{array}$ & $\begin{array}{l}\text { CS and BG-PVS were } \\
\text { associated with } \\
\text { probable CAA, } \\
\text { moderate-to-severe } \\
\text { WM hyperintensities, } \\
\text { cortical superficial } \\
\text { siderosis, cerebral } \\
\text { microbleeds } \\
\text { CS-PVS was } \\
\text { separately associated } \\
\text { with strictly lobar } \\
\text { cerebral microbleeds. } \\
\text { BG-PVS was } \\
\text { associated with strictly } \\
\text { deep cerebral } \\
\text { microbleeds } \\
\text { and lacunes. }\end{array}$ & $\begin{array}{l}\text { Association of SVD } \\
\text { score with reduced } \\
\text { cortical thickness } \\
\text { across a number of } \\
\text { regions, in particular in } \\
\text { frontal and superior } \\
\text { temporal regions }\end{array}$ \\
\hline
\end{tabular}

\#In this study, the mean age of all participants and also the mean age of each subgroup according to the PVS count was expressed.

\#\#This was a prospective, population-based cohort study that aimed to examine whether EPVS are associated with presence SVD neuroradiological markers and increased risk of dementia.

\#\#\# In this study, mean age of all participants was expressed based on 4 subgroups according to the PVS count.

\#\#\#\# In this study, only the mean age of all participants was specified.

AD, Alzheimer's disease; aMCI, amnestic Mild Cognitive Impairment; sVMCI, Subcortical vascular Mild Cognitive Impairment; BG, basal ganglia; CAA, Cerebral Amyloid Angiopathy; CIND, Cognitive Impairment With No Dementia; CS, Centrum Semiovale; EPVS, Enlarged Perivascular Spaces; FTD, Frontotemporal Dementia; HC, healthy control; MCI, Mild Cognitive Impairment; PiB PET, Pittsburgh compound B PET; SCI, Subjective Cognitive Impairment; VaD, Vascular Dementia; WM, White Matter 
TABLE 2 | Clinical and MRI correlates of perivascular spaces in previous structural neuroimaging studies on patients with Parkinson's Disease.

\begin{tabular}{|c|c|c|c|c|c|c|c|}
\hline & Laitinen et al. (2000) & Mestre et al. (2014) & Lee et al. (2015a) & $\begin{array}{l}\text { Conforti et al. } \\
\text { (2014) }\end{array}$ & Park et al. (2019) & Shibata et al. (2019) & Wan et al. (2019) \\
\hline $\begin{array}{l}\text { Number of subjects } \\
\text { (Number of females) }\end{array}$ & PD: 40 & PD: 3 (1) & $\begin{array}{l}\text { PD: } 4 \\
\text { FTD: } 1 \\
\text { PSP: } 1 \\
\text { MSA: } 2 \\
\text { VaP: } 3\end{array}$ & PD: 1 (1) & $\begin{array}{l}\text { PD: } 271 \text { (N/A) } \\
\text { [106 patients with } \\
\text { intact cognition } \\
\text { (PD-IC) and } 165 \\
\text { patients with mild } \\
\text { cognitive } \\
\text { impairment (PD-MCI)] }\end{array}$ & PD: 71 (32) & PD: 137 (53) \\
\hline Age (mean $\pm S D$, year) & 62.9 & $\begin{array}{l}\text { a } 61 \text {-year-old } \\
\text { left-handed man; } \\
\text { a } 41 \text {-year-old } \\
\text { right-handed woman; } \\
\text { a } 52 \text {-year-old } \\
\text { left-handed man }\end{array}$ & 72 & 69 & $\mathrm{~N} / \mathrm{A}$ & $73.2 \pm 8.4$ & $68.1 \pm 8.6$ \\
\hline MRI scanner & $1 \mathrm{~T}$ & $3 \mathrm{~T}$ & N/A & $3 \mathrm{~T}$ & 3Т & $1.5 \mathrm{~T}$ & $3 \mathrm{~T}$ \\
\hline EPVS quantification & Visual rating & Visual rating & $\begin{array}{l}\text { Visual semi-quantitative scale } \\
\text { (none }=0 \text {, mild }=1 \text {, moderate }=2 \text {, } \\
\text { severe }=3 \text { ) and a quantitative } \\
\text { scale by counting the actual } \\
\text { number of EPVS [ } 0 \text { (none), } 1-9 \\
=1 \text { (mild), } 10-19=2 \text { (moderate), } \\
\text { and } \geq 20=3 \text { (severe)] } \\
\text { in six segments (each striatum } \\
\text { was divided into three segments: } \\
C N, A P \text { and PP). }\end{array}$ & $\begin{array}{l}\text { Semi- automated } \\
\text { rating }\end{array}$ & $\begin{array}{l}\text { PVS was rated in the } \\
\text { BG and CS using a } \\
4 \text {-point visual scale } \\
\text { and then classified as } \\
\text { high (score } \geq 2 \text { ) or } \\
\text { low (score }<2 \text { ) } \\
\text { according to severity }\end{array}$ & $\begin{array}{l}\text { Visual rating. } \\
\text { Use of total SVD } \\
\text { score (range: 0-4) } \\
\text { based on white } \\
\text { matter hyper } \\
\text { intensities } \\
\text { (WMHs), lacunae, } \\
\text { cerebral microbleeds } \\
\text { (MBs), and EPVS }\end{array}$ & $\begin{array}{l}\text { Visual rating in } B G \\
\text { and } C S\end{array}$ \\
\hline $\begin{array}{l}\text { Association of EPVS } \\
\text { with PD }\end{array}$ & $\mathrm{N} / \mathrm{A}$ & $\begin{array}{l}\text { Single large EPVS } \\
\text { contralateral to } \\
\text { symptoms side }\end{array}$ & $\begin{array}{l}\text { no significant correlation } \\
\text { between the presence of EPVS } \\
\text { and abnormality of the DaT-PET }\end{array}$ & $\begin{array}{l}\text { Single giant EPVS in } \\
\text { the left anterior } \\
\text { perforated substance }\end{array}$ & $\begin{array}{l}\text { In all patients, higher } \\
\text { BG-PVS severity was } \\
\text { an independent } \\
\text { positive predictor of } \\
\text { future cognitive } \\
\text { decline. } \\
\text { (mean follow-up of } \\
5.0 \pm 2.3 \text { years) }\end{array}$ & $\begin{array}{l}\text { No significant } \\
\text { associations with } \\
\text { total SVD score and } \\
\text { PD severity and } \\
\text { motor phenotype }\end{array}$ & $\mathrm{N} / \mathrm{A}$ \\
\hline $\begin{array}{l}\text { Association of EPVS } \\
\text { with clinical or } \\
\text { demographic variables }\end{array}$ & $\begin{array}{l}\text { Patients with predominantly } \\
\text { right-sided symptoms had larger } \\
\text { EPVS in the right compared with } \\
\text { left globus pallidus and larger } \\
\text { EPVS in the left putamen than in } \\
\text { the right. The pattern for patients } \\
\text { with predominantly left-sided } \\
\text { symptoms was completely } \\
\text { reversed. The size, site, and } \\
\text { distribution of the EPVS did not } \\
\text { correlate with the patients' age or } \\
\text { sex, nor with duration of illness or } \\
\text { HY stage }\end{array}$ & $\begin{array}{l}\text { Hypothesized } \\
\text { association of a } \\
\text { single large EPVS } \\
\text { may contribute to } \\
\text { atypical clinical } \\
\text { features in patients } \\
\text { who otherwise had } \\
\text { clinical/imaging } \\
\text { findings consistent } \\
\text { with idiopathic PD }\end{array}$ & $\begin{array}{l}\text { The EPVS score was significantly } \\
\text { correlated with K-MMSE, } \\
\text { MoCA-K, and FAB, but not with } \\
\text { HY stage }\end{array}$ & $\begin{array}{l}\text { Symptoms affecting } \\
\text { predominantly the } \\
\text { right limbs }\end{array}$ & $\mathrm{N} / \mathrm{A}$ & $\begin{array}{l}\text { Increasing age and } \\
\text { reduced MMSE and } \\
\text { MoCA scores were } \\
\text { associated with } \\
\text { increased SVD } \\
\text { burden }\end{array}$ & $\begin{array}{l}\text { Association between } \\
\text { EPVS in BG and the } \\
\text { tremor score ( } p= \\
0.032 \text { ) }\end{array}$ \\
\hline
\end{tabular}




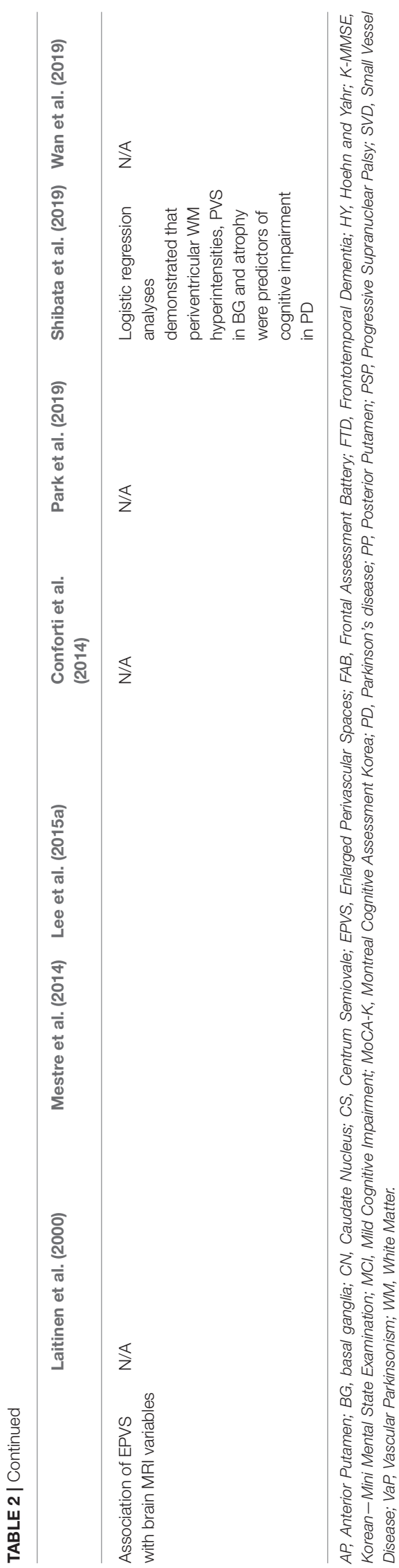

with diameter generally smaller than $3 \mathrm{~mm}$, and signal intensity similar to the CSF. The assessment of EPVS on MRI mainly relies on visual methods to identify and count their number at specific brain locations where they are more likely to become apparent: the centrum semiovale, basal ganglia, hippocampus, and brainstem (Patankar et al., 2005; Adams et al., 2013, 2015; Potter et al., 2015). Automated methods for the detection and quantification of EPVS are being developed with the promise of improving sensitivity and robustness in detecting EPVS changes (Ballerini et al., 2018; Boespflug et al., 2018; Dubost et al., 2019).

\section{EPVS in Neurodegenerative and Cerebrovascular Diseases}

Several studies have consistently shown associations of MRIvisible EPVS in the basal ganglia with hypertension, as well as with other correlates of cerebral small vessel disease, such as cerebral white matter hyperintensities, lacunes, microbleeds, and retinal vessel abnormalities (Rouhl et al., 2008; Doubal et al., 2010; Zhu et al., 2010; Klarenbeek et al., 2013; Wardlaw et al., 2013; Hansen et al., 2015; Mutlu et al., 2016; Ramirez et al., 2016; Arba et al., 2018). By contrast, MRI-visible EPVS in the cerebral white matter of the centrum semiovale are not typically associated with vascular risk factors, but are associated with advanced age (Doubal et al., 2010; Charidimou et al., 2013), AD (Roher et al., 2003; Chen et al., 2011; Banerjee et al., 2017) and cerebral amyloid angiopathy (Martinez-Ramirez et al., 2013; Charidimou et al., 2015, 2017; van Veluw et al., 2016).

The role of EPVS in the context of the glymphatic clearance of $A \beta$ has been scrutinized in neuroimaging studies investigating the association between EPVS and A $\beta$ deposition in cerebral amyloid angiopathy and AD. A recent study examined EPVS postmortem using MRI in five amyloid-positive brains and found a topographical association between EPVS and cortical amyloid deposition (van Veluw et al., 2016). Since no association was found between EPVS and amyloid plaques or vasculopathy related to cerebral amyloid angiopathy, the authors hypothesized that the deposition of $A \beta$ in cortical and leptomeningeal vessels impairs the interstitial fluid clearance, resulting in retrograde enlargement of the perivascular space. Kasahara et al. (2019) found relatively higher EPVS in amyloid positron emission tomography (PET)-positive compared to PET-negative patients, although the differences were not significant. Banerjee et al. (2018) found that EPVS of the centrum semiovale were associated with amyloid PET positivity, although the association was not significant in analyses adjusted for demographics and vascular risk factors. Charidimou et al. $(2014,2015)$ reported that larger EPVS of the centrum semiovale were more frequent in patients with cerebral amyloid angiopathy compared to controls. In summary, to date the available literature does not provide compelling evidence of association between severity of EPVS and amyloid deposition as measured by PET (Table 1). One possible explanation for the lack of association between EPVS and amyloid PET findings might be the fact that, due to limited spatial resolution of PET imaging, PET-visible amyloid is considered to reflect parenchymal deposits, while MRI-visible EPVS may 
TABLE 3 | Clinical and MRI correlates of perivascular spaces in previous structural neuroimaging studies on patients with multiple sclerosis

\begin{tabular}{|c|c|c|c|c|c|c|c|}
\hline & $\begin{array}{l}\text { Achiron and Faibel } \\
(2002)\end{array}$ & Wuerfel et al. (2008) & $\begin{array}{l}\text { Etemadifar et al. } \\
\text { (2011) }\end{array}$ & Al-Saeed et al. (2012) & Conforti et al. (2014) & Kilsdonk et al. (2015) & Cavallari et al. (2018) \\
\hline $\begin{array}{l}\text { Number of subjects } \\
\text { (Number of females) }\end{array}$ & $\begin{array}{l}\text { MS: } 71(47) \\
\text { HC: } 60(38)\end{array}$ & $\begin{array}{l}\text { MS: } 45(23) \\
\text { HC: } 30(16)\end{array}$ & $\begin{array}{l}\text { MS: } 73 \text { (55) } \\
\text { HC: } 73 \text { (55) }\end{array}$ & $\begin{array}{l}\text { MS: } 80(N / A) \\
H C: 80(N / A)\end{array}$ & $\begin{array}{l}\text { MS: } 40(28) \\
\text { HC: } 30(17)\end{array}$ & $\begin{array}{l}\text { MS: } 34 \text { (22) } \\
\text { HC: } 11 \text { (6) }\end{array}$ & $\begin{array}{l}\text { MS: } 60 \text { (48) } \\
\text { HC: } 15 \text { (9) }\end{array}$ \\
\hline Phenotype & $\mathrm{N} / \mathrm{A}$ & $45 \mathrm{RRMS}$ & $\mathrm{N} / \mathrm{A}$ & N/A & 40 RRMS & $\begin{array}{l}22 \text { RRMS } \\
5 \text { SPMS } \\
7 \text { PPMS }\end{array}$ & $\begin{array}{l}\text { C MS: } 30 \text { (24) } \\
\text { NC MS: } 30 \text { (24) }\end{array}$ \\
\hline Age (mean \pm SD, year) & $\begin{array}{l}\text { MS: } 26.8 \pm 9.2 \\
\text { C: } 27.2 \pm 8.4\end{array}$ & $\begin{array}{l}\text { MS: } 39.8 \pm 8.2 \\
\text { C: } 37.8 \pm 11.5\end{array}$ & $\begin{array}{l}\text { MS: } 32.3 \pm 9.3 \\
\text { HC: } 33.3 \pm 10.0\end{array}$ & $\begin{array}{l}\text { MS: } 15-49^{\#} \\
\text { HC: N/A }\end{array}$ & $\begin{array}{l}\text { MS: } 42.7 \pm 8.0 \\
\text { C: } 42.8 \pm 8.9\end{array}$ & $\begin{array}{l}\text { MS: } 43.0 \pm 7.9 \\
\text { C: } 38.8 \pm 10.5\end{array}$ & $\begin{array}{l}\text { C MS: } 50(27-68)^{\# \#} \\
\text { NC MS: } 48(27-63)^{\# \#} \\
\text { HC: } 38(24-56)^{\# \#}\end{array}$ \\
\hline 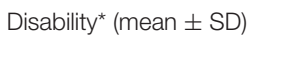 & N/A & $2.3 \pm 1.4$ & $\mathrm{~N} / \mathrm{A}$ & N/A & $(1-6.5)^{\star \star}$ & $4(0-7.5)^{\# \#}$ & $\begin{array}{l}\text { C MS: } 2(0-2)^{\# \#} \\
\text { NC MS: } 0(0-2)^{\# \#}\end{array}$ \\
\hline $\begin{array}{l}\text { Disease duration (mean } \pm \\
S D \text {, year) }\end{array}$ & $<0.3$ & $8.8 \pm 6.2$ & $<0.3$ & $<0.3$ & $>10$ & $9.4 \pm 5.8$ & $\begin{array}{l}\text { C MS: } 12 \text { (2-30) \#\# } \\
\text { NC MS: } 12 \text { (2-30) \#\# }\end{array}$ \\
\hline MRI scanner & $2 T$ & $1.5 T$ & $1.5 \mathrm{~T}$ & $1.5 \mathrm{~T}$ & $3 T$ & $7 \mathrm{~T}$ & $1.5 T$ \\
\hline VRS quantification & $\begin{array}{l}\text { Manual VRS counting in } \\
\text { centrum semiovale. }\end{array}$ & $\begin{array}{l}\text { Semi-automated VRS } \\
\text { counting and volume } \\
\text { measurements in basal } \\
\text { ganglia and centrum } \\
\text { semiovale. }\end{array}$ & $\begin{array}{l}\text { Manual VRS counting in } \\
\text { brainstem, basal ganglia } \\
\text { and centrum semiovale. }\end{array}$ & $\begin{array}{l}\text { Manual VRS counting in } \\
\text { brainstem, basal ganglia } \\
\text { and centrum semiovale. }\end{array}$ & $\begin{array}{l}\text { Semi-automated VRS } \\
\text { counting, area and } \\
\text { volume measurements } \\
\text { in typical (brainstem, } \\
\text { basal ganglia, centrum } \\
\text { semiovale) as well as } \\
\text { atypical regions. }\end{array}$ & $\begin{array}{l}\text { Manual VRS counting in } \\
\text { the brain convexity } \\
\text { (handknob), anterior } \\
\text { crus, anterior } \\
\text { commissure, third } \\
\text { ventricle-aqueduct } \\
\text { transition including basal } \\
\text { ganglia, peduncules. }\end{array}$ & $\begin{array}{l}\text { Manual VRS counting in } \\
\text { brainstem, basal ganglia } \\
\text { and centrum semiovale. }\end{array}$ \\
\hline $\begin{array}{l}\text { Association of VRSs with } \\
\text { MS }\end{array}$ & $\begin{array}{l}\text { Higher VRS count in MS } \\
\text { versus HC. }\end{array}$ & $\begin{array}{l}\text { Significantly higher VRS } \\
\text { volume in MS versus HC } \\
\text { independent of BPF. No } \\
\text { difference in VRS count } \\
\text { between MS and HC. }\end{array}$ & $\begin{array}{l}\text { Significantly higher total } \\
\text { and centrum semiovale } \\
\text { VRS count in MS versus } \\
\text { HC. }\end{array}$ & $\begin{array}{l}\text { No significant difference } \\
\text { in VRS count between } \\
\text { MS and HC. }\end{array}$ & $\begin{array}{l}\text { Significantly higher total } \\
\text { and atypical VRS count } \\
\text { in MS versus HC. }\end{array}$ & $\begin{array}{l}\text { Significantly higher total, } \\
\text { brain convexity and } \\
\text { anterior crus VRS count } \\
\text { in MS versus HC. }\end{array}$ & $\begin{array}{l}\text { Significantly higher total, } \\
\text { basal ganglia and } \\
\text { brainstem VRS count, } \\
\text { and marginally higher } \\
\text { centrum semiovale VRS } \\
\text { count in MS versus HC. } \\
\text { No difference between } \\
\text { C MS and NC MS. }\end{array}$ \\
\hline $\begin{array}{l}\text { Association of VRSs with } \\
\text { clinical or demographic } \\
\text { variables }\end{array}$ & $\begin{array}{l}\text { No association with age } \\
\text { of onset, physical } \\
\text { disability, specific } \\
\text { functional system } \\
\text { involvement, mono- or } \\
\text { polysymptomatic } \\
\text { involvement. }\end{array}$ & $\begin{array}{l}\text { No significant } \\
\text { association with age, } \\
\text { disease duration, } \\
\text { physical disability, the } \\
\text { time since last relapse or } \\
\text { with immunomodulatory } \\
\text { treatment. }\end{array}$ & $\begin{array}{l}\text { Significantly higher total } \\
\text { and centrum semiovale } \\
\text { VRS count in male } \\
\text { versus female MS } \\
\text { patients. }\end{array}$ & $\begin{array}{l}\text { No significant } \\
\text { association with age or } \\
\text { gender. }\end{array}$ & $\mathrm{N} / \mathrm{A}$ & $\begin{array}{l}\text { Significant negative } \\
\text { association of VRS with } \\
\text { age and disease } \\
\text { duration. No association } \\
\text { with physical disability. }\end{array}$ & $\begin{array}{l}\text { Marginally significant } \\
\text { positive correlation with } \\
\text { disease duration. The } \\
\text { observed difference in } \\
\text { VRS count between MS } \\
\text { and HC was not } \\
\text { independent from age } \\
\text { and sex. }\end{array}$ \\
\hline $\begin{array}{l}\text { Association of VRSs with } \\
\text { brain MRI variables }\end{array}$ & $\begin{array}{l}\text { No significant } \\
\text { association with the } \\
\text { number of CELs at } \\
\text { onset. }\end{array}$ & $\begin{array}{l}\text { Significant association } \\
\text { with the occurrence of } \\
\text { CELs. No association } \\
\text { with BH, BPF and T2L. }\end{array}$ & $\mathrm{N} / \mathrm{A}$ & N/A & $\begin{array}{l}\text { No significant } \\
\text { association with BPF. }\end{array}$ & $\begin{array}{l}\text { Significant negative } \\
\text { association with BPF. } \\
\text { No association with T2L } \\
\text { count. }\end{array}$ & $\begin{array}{l}\text { No significant } \\
\text { association with BPF or } \\
\text { T2L. }\end{array}$ \\
\hline
\end{tabular}

BH, black hole; BPF, brain parenchymal fraction; C, converter from RRMS to SPMS; CEL, contrast-enhancing lesion; HC, healthy control; IMT, immunomodulatory treatment; MS, multiple sclerosis; NC, non-converter; PPMS, Primary Progressive MS; RRMS, Relapsing-Remitting MS; SPMS, Secondary Progressive MS; VRS, Virchow-Robin Spaces.

${ }^{*}$ Disability was assessed using the Expanded Disability Status Scale in MS patients.

${ }^{\star *} / n$ this study, only the range of the Expanded Disability Status Scale was specified. 20 patients had EDSS $<3.0$ and 19 patients had EDSS $>4$.

\#In this study, only the age range of MS patients was specified. MS and HC groups were age- and gender-matched.

\#\# expressed as median (range). 
be considered a correlate of vascular dysfunction resulting from vascular amyloid deposits (Weller et al., 2015).

The link between EPVS and inflammation in neurodegenerative diseases has been investigated in recent studies reporting an association between EPVS and C-reactive protein in AD and small vessel disease (Satizabal et al., 2012; Hilal et al., 2018). Results from a study by Bi et al. (2012) suggest that C-reactive protein cytotoxicity is associated with $A \beta$ formation. In rat adrenal pheochromocytoma cell lines, the levels of amyloid precursor protein, beta-site APP cleaving enzyme, and presenilins were found to be increased after treatment with subtoxic concentrations of C-reactive protein. Higher C-reactive protein levels were also associated with neuroimaging biomarkers of cerebral small vessel disease and higher plasma levels of $A \beta 1-38, A \beta 1-40$, and $A \beta 1-42$ (Hilal et al., 2018).

In the context of neurodegenerative disorders, parkinsonism with enlarged PVS in basal ganglia has been reported by several authors through the years (Fenelon et al., 1995; Mancardi et al., 1998; Duker and Espay, 2007; Mehta et al., 2013; Lee et al., 2015b). Their clinical significance remains unclear but in recent articles enlargement of PVS was found to be predictive of cognitive impairment in PD (Park et al., 2019; Shibata et al., 2019) and related to motor symptoms (Laitinen et al., 2000; Mestre et al., 2014; Lee et al., 2015a; Conforti et al., 2018; Wan et al., 2019). However, the validation of these observations is lacking, and the mechanisms by which enlarged PVS negatively affect motor and cognitive changes in PD remain largely unknown (see Table 2).

\section{EPVS in MS}

Although EPVS have been traditionally considered correlates of neurological diseases with primarily neurodegenerative or vascular pathogenesis, they have been also observed in neuroinflammatory diseases. Inflammatory cells accumulating in the perivascular space can damage the extracellular matrix, impair the integrity of $\mathrm{BBB}$, and potentially lead to demyelination (Wong et al., 2013). Although the interaction between inflammatory cells, EPVS, and CSF dynamics has not yet been studied in detail, it is conceivable that the aggregation of inflammatory cells in the perivascular space could also obstacle the glymphatic clearance.

EPVS burden in MS was first assessed by Achiron and Faibel (2002) in a cohort of recent-onset MS patients. Most neuroimaging studies of EPVS in MS consistently showed that the number (Etemadifar et al., 2011; Conforti et al., 2014; Kilsdonk et al., 2015; Cavallari et al., 2018) and volume (Wuerfel et al., 2008) of EPVS was higher in MS patients compared to healthy controls (Table 3), with the exception of one study that failed to replicate these findings (Al-Saeed et al., 2012). The location of EPVS most consistently associated with MS was the centrum semiovale (Achiron and Faibel, 2002; Etemadifar et al., 2011; Kilsdonk et al., 2015; Cavallari et al., 2018). EPVS also appeared to be more frequent in atypical sites in MS patients compared to controls (Kwee and Kwee, 2007).

Studies of the association of EPVS with clinical and neuroimaging features of MS showed less consistent results
(Table 3). While a few studies showed significant associations of EPVS with age (Kilsdonk et al., 2015), disease duration (Kilsdonk et al., 2015; Cavallari et al., 2018) and sex (Etemadifar et al., 2011), others failed to replicate those findings (Achiron and Faibel, 2002; Wuerfel et al., 2008). Most studies reported no association of EPVS with physical disability (Achiron and Faibel, 2002; Wuerfel et al., 2008; Kilsdonk et al., 2015) or conversion to secondary-progressive MS (Cavallari et al., 2018). A 7T MRI study by Kildonsk et al. found that higher EPVS count was associated with global brain atrophy, while other studies using lower field MRI (i.e., 1.5T or 3T) failed to replicate this finding (Wuerfel et al., 2008; Conforti et al., 2014; Cavallari et al., 2018). Two MRI studies investigated the association of EPVS with clinical relapses and the occurrence of enhancing lesions in MS. A cross-sectional MRI study by Achiron et al. found no association between EPVS of the centrum semiovale and contrast enhancing lesions in MS patients within 3 months of disease onset. Wuerfel et al. showed that EPVS count and volume increased during clinical or radiological relapses, thus supporting the hypothesis that EPVS in MS are associated with neuroinflammatory changes. This study provided for the first time evidence of dynamic perivascular space changes in response to inflammation. Further longitudinal studies are needed to confirm and characterize the pathophysiological correlates of perivascular space changes, and ultimately contribute to clarify the role of EPVS not only in neuroinflammatory but also in neurodegenerative and cerebrovascular diseases.

\section{CONCLUSIONS}

The perivascular unit represents a crossroad where neurodegenerative, neuroinflammatory and cerebrovascular mechanisms of brain injury dynamically interact. Those mechanisms gravitate around the glymphatic pathway of clearance, of which the perivascular space represents a crucial component. Although confirmatory studies are warranted to clarify the interaction between those mechanisms of brain injury in humans, seminal work in animal models has pointed to the glymphatic pathway as a potential novel mechanism of neuroprotection with implications for neurodegenerative, neuroinflammatory, and cerebrovascular disorders. The assessment of MRI-visible EPVS dynamics, as well as emerging and more advanced neuroimaging approaches to assess directly glymphatic dynamics may provide surrogate biomarkers to clarify the relevance of the PVU and glymphatic clearance to neurological diseases in humans.

\section{AUTHOR CONTRIBUTIONS}

FT wrote the review. VC and MM gave their contributions on small vessel disease and AD. EM, MP, VR, and CR helped in the part of neuroimmunology and neuroinflammation. FO, MC, CG, FG, GR, and MS helped in critically reviewing the manuscript. 


\section{REFERENCES}

Achiron, A., and Faibel, M. (2002). Sandlike appearance of Virchow-Robin spaces in early multiple sclerosis: a novel neuroradiologic marker. AJNR Am. J. Neuroradiol. 23, 376-380.

Adams, H. H., Cavalieri, M., Verhaaren, B. F., Bos, D., van der Lugt, A., Enzinger, C., et al. (2013). Rating method for dilated VirchowRobin spaces on magnetic resonance imaging. Stroke 44, 1732-1735. doi: 10.1161/STROKEAHA.111.000620

Adams, H. H., Hilal, S., Schwingenschuh, P., Wittfeld, K., van der Lee, S. J., DeCarli, C., et al. (2015). A priori collaboration in population imaging: the uniform neuro-imaging of virchowrobin spaces enlargement consortium. Alzheimers Dement (Amst) 1, 513-520. doi: 10.1016/j.dadm.2015. 10.004

Al-Saeed, O., Athyal, R., Ismail, M., and Sheikh, M. (2012). Significance of Virchow-Robin spaces in patients newly diagnosed with multiple sclerosis: a case-control study in an Arab population. Med. Princ. Pract. 21, 447-451. doi: $10.1159 / 000337427$

Arba, F., Quinn, T. J., Hankey, G. J., Lees, K. R., Wardlaw, J. M., Ali, M., et al. (2018). Enlarged perivascular spaces and cognitive impairment after stroke and transient ischemic attack. Int. J. Stroke 13, 47-56. doi: $10.1177 / 1747493016666091$

Arbel-Ornath, M., Hudry, E., Eikermann-Haerter, K., Hou, S., Gregory, J. L., Zhao, L., et al. (2013). Interstitial fluid drainage is impaired in ischemic stroke and Alzheimer's disease mouse models. Acta Neuropathol. 126, 353-364. doi: 10.1007/s00401-013-1145-2

Armulik, A., Abramsson, A., and Besholtz C. (2005). Endothelial/pericyte interactions. Circ. Res. 97, 512-523. doi: 10.1161/01.RES.0000182903.16652.d7

Armulik, A., Genové, G., Mäe, M., Nisancioglu, M. H., Wallgard, E., Niaudet, C., et al. (2010). Pericytes regulate the blood-brain barrier. Nature 468, 557-561. doi: 10.1038/nature09522

Ballerini, L., Lovreglio, R., Valdés Hernández MDC, Ramirez, J., MacIntosh, B. J., Black, S. E., et al. (2018). Perivascular spaces segmentation in brain MRI using optimal 3D filtering. Sci. Rep. 8:2132. doi: 10.1038/s41598-01819781-5

Banerjee, G., Jang, H., Kim, H. J., Kim, S. T., Kim, J. S., Lee, J. H., et al. (2018). Total MRI small vessel disease burden correlates with cognitive performance. cortical atrophy and network measures in a memory clinic population. J. Alzheimers Dis. 63, 1485-1497. doi: 10.3233/JAD-1 70943

Banerjee, G., Kim, H. J., Fox, Z., Jäger, H. R., Wilson, D., Charidimou, A., et al. (2017). MRI-visible perivascular space location is associated with Alzheimer's disease independently of amyloid burden. Brain 140, 1107-1116. doi: 10.1093/brain/awx003

Barger, S. W., and Harmon, A. D. (1997). Microglial activation by Alzheimer amyloid precursor protein and modulation by apolipoprotein E. Nature 388, 878-881. doi: $10.1038 / 42257$

Bi, B. T., Lin, H. B., Cheng, Y. F., Zhou, H., Lin, T., Zhang, M. Z., et al. (2012). Promotion of $\beta$-amyloid production by $\mathrm{C}$-reactive protein and its implications in the early pathogenesis of Alzheimer's disease. Neurochem. Int. 60, 257-266. doi: 10.1016/j.neuint.2011.12.007

Blanco, A., Alvarez, S., Fresno, M., and Muñoz-Fernández, M. Á. (2010). Amyloid- $\beta$ induces cyclooxygenase-2 and PGE2 release in human astrocytes in NF-K B dependent manner. J. Alzheimers Dis. 22, 493-505. doi: 10.3233/JAD-2010-100309

Boespflug, E. L., Schwartz, D. L., Lahna, D., Pollock, J., Iliff, J. J., Kaye, J. A., et al. (2018). MR Imaging-based Multimodal Autoidentification of Perivascular Spaces (mMAPS): Automated Morphologic Segmentation of Enlarged Perivascular Spaces at Clinical Field Strength. Radiology 286, 632-642. doi: 10.1148/radiol.2017170205

Breen, D. P., Vuono, R., Nawarathna, U., Fisher, K., Shneerson, J. M., Reddy, A. B., et al. (2014). Sleep and circadian rhythm regulation in early Parkinson disease. JAMA Neurol. 71, 589-595.56. doi: 10.1001/jamaneurol.2 014.65

Cai, Y., Liu, S., Sothern, R. B., Xu, S., and Chan P. (2010). Expression of clock genes Perl and Bmall in total leukocytes in health and Parkinson's disease. Eur. J. Neurol. 17, 550-554. doi: 10.1111/j.1468-1331.2009. 02848.x
Carare, R. O., Bernardes-Silva, M., Newman, T. A., Page, A. M., Nicoll JAR, Perry, V. H., et al. (2008). Solutes, but not cells, drain from the brain parenchyma along basement membranes of capillaries and arteries. Significance for cerebral amyloid angiopathy and neuroimmunology. Neuropathol. Appl. Neurobiol. 34, 131-144. doi: 10.1111/j.1365-2990.2007. 00926.x

Cavallari, M., Egorova, S., Healy, B. C., Palotai, M., Prieto, J. C., Polgar-Turcsanyi, M., et al. (2018). Evaluating the Association between Enlarged Perivascular Spaces and Disease Worsening in Multiple Sclerosis. J. Neuroimaging. 28, 273-277. doi: 10.1111/jon.12490

Charidimou, A., Boulouis, G., Pasi, M., Auriel, E., van Etten, E. S., Haley, K., et al. (2017). MRI-visible perivascular spaces in cerebral amyloid angiopathy and hypertensive arteriopathy. Neurology 88, 1157-1164. doi: 10.1212/WNL.0000000000003746

Charidimou, A., Hong, Y. T., Jager, H. R., Fox, Z., Aigbirhio, F. I., Fryer, T. D., et al. (2015). White matter perivascular spaces on magnetic resonance imaging: marker of cerebrovascular amyloid burden? Stroke 46, 1707-1709. doi: 10.1161/STROKEAHA.115.009090

Charidimou, A., Jaunmuktane, Z., Baron, J. C., Burnell, M., Varlet, P., Peeters, A., et al. (2014). White matter perivascular spaces: an MRI marker in pathology-proven cerebral amyloid angiopathy? Neurology 82, 57-62. doi: 10.1212/01.wnl.0000438225.02729.04

Charidimou, A., Meegahage, R., Fox, Z., Peeters, A., Vandermeeren, Y., Laloux, P., et al. (2013). Enlarged perivascular spaces as a marker of underlying arteriopathy in intracerebral haemorrhage: a multicentre MRI cohort study. J. Neurol. Neurosurg. Psychiatry 84, 624-629. doi: 10.1136/jnnp-2012-3 04434

Chen, W., Song, X., Zhang, Y., Alzheimer's Disease Neuroimaging Initiative (2011). Assessment of the Virchow-Robin Spaces in Alzheimer disease, mild cognitive impairment, and normal aging, using high-field MR imaging. AJNR Am. J. Neuroradiol. 32, 1490-1495. doi: 10.3174/ajnr. A2541

Choe, Y., Huynh, T., and Pleasure, S. J. (2014). Migration of oligodendrocyte progenitor cells is controlled by transforming growth factor $\beta$ family proteins during corticogenesis. J. Neurosci. 34, 14973-14983. doi: 10.1523/JNEUROSCI.1156-14.2014

Conforti R, Sardaro, A., Negro, A., Caiazzo, G., Paccone, A., De Micco, R., et al. (2018). Dilated Virchow-Robin space and Parkinson's disease: A case report of combined MRI and diffusion tensor imaging. Radiol. Case Rep. 13, 871-877. doi: 10.1016/j.radcr.2018.05.011

Conforti, R., Cirillo, M., Saturnino, P. P., Gallo, A., Sacco, R., Negro, A., et al. (2014). Dilated Virchow-Robin spaces and multiple sclerosis: $3 \mathrm{~T}$ magnetic resonance study. Radiol. Med. 119, 408-414. doi: 10.1007/s11547-013-0357-9

da Fonseca, A. C., Matias, D., Garcia, C., Amaral, R., Geraldo, L. H., Freitas, C., et al. (2014). The impact of microglial activation on blood-brain barrier in brain diseases. Front. Cell Neurosci. 8:362. doi: 10.3389/fncel.2014.00362

de Leon, M. J., Li, Y., Okamura, N., Tsui, W. H., Saint-Louis, L. A., Glodzik, L., et al. (2017). Cerebrospinal fluid clearance in alzheimer disease measured with dynamic PET. J. Nucl. Med. 58, 1471-1476. doi: 10.2967/jnumed.116.187211

de Vos, A. F., van Meurs, M., Brok, H. P., Boven, L. A., Hintzen, R. Q., van der Valk, P., et al. (2002). Transfer of central nervous system autoantigens and presentation in secondary lymphoid organs. J. Immunol. 169, 5415-5423. doi: 10.4049/jimmunol.169.10.5415

Ding, J., Sigurð^sson, S., Jónsson, P. V., Eiriksdottir, G., Charidimou, A., Lopez, O. L., et al. (2017). Large perivascular spaces visible on magnetic resonance imaging. cerebral small vessel disease progression and risk of dementia: the age gene/environment susceptibility-reykjavik study. JAMA Neurol. 74, 1105-1112. doi: 10.1001/jamaneurol.2017.1397

Domingues, H. S. (2016). Oligodendrocyte astrocyte and microglia crosstalk in myelin development damage, and repair. Front. Cell Dev. Biol. 4:71. doi: $10.3389 /$ fcell.2016.00071

Doubal, F. N., MacLullich, A. M., Ferguson, K. J., Dennis, M. S., and Wardlaw, J. M. (2010). Enlarged perivascular spaces on MRI are a feature of cerebral small vessel disease. Stroke 41, 450-454. doi: 10.1161/STROKEAHA.109. 564914

Dubost, F., Yilmaz, P., Adams, H., Bortsova, G., Ikram, M. A., Niessen, W., et al. (2019). Enlarged perivascular spaces in brain MRI: Automated quantification in four regions. Neuroimage 185, 534-544. doi: 10.1016/j.neuroimage.2018.10.026 
Dudvarski Stankovic, N., Teodorczyk, M., Ploen, R., Zipp, F., and Schmidt, M. H. H. (2016). Microglia-blood vessel interactions: a double-edged sword in brain pathologies. Acta Neuropathol. 131, 347-363. doi: 10.1007/s00401-015-1524-y

Duker, A. P., and Espay, A. J. (2007). Parkinsonism associated with striatal perivascular space dilation. Neurology 68:1540. doi: 10.1212/01.wnl.0000261483.49248.b8

Eide, P. K., Vatnehol, S. A. S., Emblem, K. E., and Ringstad, G. (2018). Magnetic resonance imaging provides evidence of glymphatic drainage from human brain to cervical lymph nodes. Sci. Rep. 8:7194. doi: 10.1038/s41598-018-25666-4

Emmanouilidou, E., Elenis, D., Papasilekas, T., Stranjalis, G., Gerozissis, K., Ioannou, P. C., et al. (2011). Assessment of $\alpha$-synuclein secretion in mouse and human brain parenchyma. PLoS ONE 6:e22225. doi: 10.1371/journal.pone.0022225

Engelhardt, B., Carare, R. O., Bechmann, I., Flügel, A., Laman, J. D., Weller, R. O. et al. (2016). Vascular, glial, and lymphatic immune gateways of the central nervous system. Acta Neuropathol. 132, 317-338. doi: 10.1007/s00401-016-1606-5

Engelhardt, B., and Coisne, C. (2011). Fluids and barriers of the CNS establish immune privilege by confining immune surveillance to a twowalled castle moat surrounding the CNS castle. Fluids Barriers CNS 8:4. doi: 10.1186/2045-8118-8-4

Engelhardt, B., and Liebner S. (2014). Novel insights into the development and maintenance of the blood-brain barrier. Cell Tissue Res. 355, 687-699. doi: 10.1007/s00441-014-1811-2

Etemadifar, M., Hekmatnia, A., Tayari, N., Kazemi, M., Ghazavi, A., Akbari, M., et al. (2011). Features of Virchow-Robin spaces in newly diagnosed multiple sclerosis patients. Eur. J. Radiol. 80:e104-8. doi: 10.1016/j.ejrad.2010. 05.018

Fabriek, B. O., Zwemmer, J. N., Teunissen, C. E., Dijkstra, C. D., Polman, C. H., Laman, J. D., et al. (2005). In vivo detection of myelin proteins in cervical lymph nodes of MS patients using ultrasound-guided fineneedle aspiration cytology. J. Neuroimmunol. 161, 190-194. doi: 10.1016/j.jneuroim.2004. 12.018

Fenelon, G., Gray, F., Wallays, C., Poirier, J., and Guillard, A. (1995). Parkinsonism and dilatation of the perivascular spaces (etat crible) of the striatum: a clinical, magnetic resonance imaging, and pathological study. Mov. Disord. 10, 754-760. doi: $10.1002 / \mathrm{mds} .870100609$

Ferland-McCollough, D., Slater, S., Richard, J., Reni, C., and Mangialardi G. (2017). Pericytes, an overlooked player in vascular pathobiology. Pharmacol. Ther. 171, 30-42. doi: 10.1016/j.pharmthera.2016.11.008

Filosa, J. A., Morrison, H. W., Iddings, J. A., Du, W., and Kim, K. J. (2016). Beyond neurovascular coupling, role of astrocytes in the regulation of vascular tone. Neuroscience 323, 96-109. doi: 10.1016/j.neuroscience.2015.03.064

Fultz, N. E., Bonmassar, G., Setsompop, K., Stickgold, R. A., Rosen, B. R., Polimeni, J. R., et al. (2019). Coupled electrophysiological, hemodynamic, and cerebrospinal fluid oscillations in human sleep. Science 366, 628-631. doi: 10.1126/science.aax 5440

Furtado, G. C., Marcondes, M. C., Latkowski, J. A., Tsai, J., Wensky, A., and Lafaille, J. J. (2008). Swift entry of myelinspecific T lymphocytes into the central nervous system in spontaneous autoimmune encephalomyelitis. J. Immunol. 181, 4648-4655. doi: 10.4049/jimmunol.181.7.4648

Gjerstad MD, Boeve, B., Wentzel-Larsen, T., Aarsland, D., and Larsen, J. P. (2008). Occurrence and clinical correlates of REM sleep behaviour disorder in patients with Parkinson's disease over time. J. Neurol. Neurosurg. Psychiatry. 79, 387-391. doi: 10.1136/jnnp.2007.116830

Goldmann, J., Kwidzinski, E., Brandt, C., Mahlo, J., Richter, D., and Bechmann I. (2006). T cells traffic from brain to cervical lymph nodes via the cribroid plate and the nasal mucosa. J. Leukoc. Biol. 80, 797-801. doi: 10.1189/jlb.0306176

Goldmann, T., Wieghofer, P., Jordão, M. J., Prutek, F., Hagemeyer, N., Frenzel, K., et al. (2016). Origin, fate and dynamics of macrophages at central nervous system interfaces. Nat. Immunol. 17, 797-805. doi: 10.1038/ni.3423

Greter, M., Heppner, F. L., Lemos, M. P., Odermatt, B. M., Goebels, N., Laufer, T., et al. (2005). Dendritic cells permit immune invasion of the CNS in an animal model of multiple sclerosis. Nat. Med. 11, 328-334. doi: 10.1038/ nm1197

Hadaczek, P., Yamashita, Y., Mirek, H., Tamas, L., Bohn, M. C., Noble, C., et al. (2006). The "perivascular pump" driven by arterial pulsation is a powerful mechanism for the distribution of therapeutic molecules within the brain. Mol. Ther. 14, 69-78. doi: 10.1016/j.ymthe.2006.02.018

Hamanaka, G., Ohtomo, R., Takase, H., Lok, J., and Arai, K. (2018). White-matter repair: Interaction between oligodendrocytes and the neurovascular unit. Brain Circ. 4, 118-123. doi: 10.4103/bc.bc_15_18

Hammes, H. P., Lin, J., Renner, O., Shani, M., Lundqvist, A., Betsholtz, C., et al. (2002). Pericytes and the pathogenesis of diabetic retinopathy. Diabetes 51, 3107-3112. doi: 10.2337/diabetes.51.10.3107

Hansen, T. P., Cain, J., Thomas, O., and Jackson A. (2015). Dilated perivascular spaces in the Basal Ganglia are a biomarker of small-vessel disease in a very elderly population with dementia. AJNR Am. J. Neuroradiol. 36, 893-898. doi: 10.3174/ajnr.A4237

Hardy, J. A., and Higgins, G. A. (1992). Alzheimer's disease: the amyloid cascade hypothesis. Science 256, 184-185. doi: 10.1126/science.1566067

Hatterer, E., Davoust, N., Didier-Bazes, M., Vuaillat, C., Malcus, C., Belin, M. F., et al. (2006). How to drain without lymphatics? Dendritic cells migrate from the cerebrospinal fluid to the B-cell follicles of cervical lymph nodes. Blood 107, 806-812. doi: 10.1182/blood-2005-01-0154

Hawkes, C. A., Gatherer, M., Sharp, M. M., Dorr, A., Yuen, H. M., Kalaria, R., et al. (2013). Regional differences in the morphological and functional effects of aging on cerebral basement membranes and perivascular drainage of amyloid- $\beta$ from the mouse brain. Aging Cell. 12, 224-326. doi: 10.1111/acel. 12045

Hawkes, C. A., Härtig, W., Kacza, J., Schliebs, R., Weller, R. O., Nicoll, J. A., et al. (2011). Perivascular drainage of solutes is impaired in the ageing mouse brain and in the presence of cerebral amyloid angiopathy. Acta Neuropathol. 121, 431-443. doi: 10.1007/s00401-011-0801-7

Hawkins, R. A., O’Kane, R. L., Simpson, I. A., and Viña, J. R. (2006). Structure of the blood-brain barrier and its role in the transport of amino acids. J. Nutr. 136(Suppl. 1), 218S-226S. doi: 10.1093/jn/136.1.218S

Hickey, W. F., and Kimura H. (1988). Perivascular microglial cells of the CNS are bone marrow-derived and present antigen in vivo. Science 239, 290-292. doi: 10.1126/science.3276004

Hilal, S., Ikram, M. A., Verbeek, M. M., Franco, O. H., Stoops, E., Vanderstichele, H., et al. (2018). C-Reactive Protein. Plasma Amyloid- $\beta$ Levels, and their Interaction with Magnetic Resonance Imaging Markers. Stroke 49, 2692-2698. doi: 10.1161/STROKEAHA.118.022317

Hirt, L., Price, M., Benakis, C., and Badaut, J. (2018). Aquaporins in neurological disorders. Clin. Transl. Neurosci. 2018, 1-7. doi: 10.1177/2514183X17752902

Hong, S., Dissing-Olesen, L., and Stevens B. (2016). New insights on the role of microglia in synaptic pruning in health and disease. Curr. Opin. Neurobiol. 36, 128-134. doi: 10.1016/j.conb.2015.12.004

Iadecola, C. (2004). Neurovascular regulation in the normal brain and in Alzheimer's disease. Nat. Rev. Neurosci. 5, 347-360. doi: 10.1038/nr n1387

Iadecola, C., and Gorelick, P. B. (2003). Converging pathogenic mechanisms in vascular and neurodegenerative dementia. Stroke 34, 335-337. doi: 10.1161/01.STR.0000054050.51530.76

Ihara, M., Tomimoto, H., Kinoshita, M., Oh, J., Noda, M., Wakita, H., et al. (2001). Chronic cerebral hypoperfusion induces MMP-2 but not MMP-9 expression in the microglia and vascular endothelium of white matter. J. Cereb. Blood Flow Metab. 21, 828-834. doi: 10.1097/00004647-200107000-00008

Iliff, J. J., Wang, M., Liao, Y., Plogg, B. A., Peng, W., Gundersen, G. A., et al. (2012). A paravascular pathway facilitates CSF flow through the brain parenchyma and the clearance of interstitial solutes, including amyloid $\beta$. Sci. Transl. Med. 4:147ra111. doi: 10.1126/scitranslmed.3003748

Iliff, J. J., Wang, M., Zeppenfeld, D. M., Venkataraman, A., Plog, B. A., Liao, Y., et al. (2013). Cerebral arterial pulsation drives paravascular CSFinterstitial fluid exchange in the murine brain. J. Neurosci.33, 18190-18199. doi: 10.1523/JNEUROSCI.1592-13.2013

Janota, C. S., Brites, D., Lemere, C. A., and Brito, M. A. (2015). Glio-vascular changes during ageing in wild-type and Alzheimer's disease-like APP/PS1 mice. Brain Res. 1620, 153-168. doi: 10.1016/j.brainres.2015.04.056

Jessen, N. A., Munk, A. S., Lundgaard, I., and Nedergaard M. (2015). The glymphatic system: a beginner's guide. Neurochem. Res. 40, 2583-2599. doi: 10.1007/s11064-015-1581-6

Kalaria, R. N. (2002). Small vessel disease and Alzheimer's dementia: pathological considerations. Cerebrovasc Dis. 13(Suppl. 2), 48-52. doi: 10.1159/000049150 
Kasahara, H., Ikeda, M., Nagashima, K., Fujita, Y., Makioka, K., Tsukagoshi, S., et al. (2019). Deep White Matter Lesions Are Associated with Early Recognition of Dementia in Alzheimer's Disease. J. Alzheimers Dis. 68, 797-808. doi: 10.3233/JAD-180939

Kawakami, N., Lassmann, S., Li, Z., Odoardi, F., Ritter, T., Ziemssen, T., et al. (2004). The activation status of neuroantigen-specific T cells in the target organ determines the clinical outcome of autoimmune encephalomyelitis. J. Exp. Med.199, 185-197. doi: 10.1084/jem.20031064

Keep, R. F., and Jones, H. C. (1990). A morphometric study on the development of the lateral ventricle choroid plexus, choroid plexus capillaries and ventricular ependyma in the rat. Brain Res. Dev. Brain Res. 56, 47-53. doi: 10.1016/0165-3806(90)90163-S

Kilsdonk, I. D., Steenwijk, M. D., Pouwels, P. J., Zwanenburg, J. J., Visser, F., Luijten, P. R., et al. (2015). Perivascular spaces in MS patients at 7 Tesla MRI: a marker of neurodegeneration? Mult. Scler. 21, 155-162. doi: $10.1177 / 1352458514540358$

Kipnis, J. (2016). Multifaceted interactions between adaptive immunity and the central nervous system. Science 353, 766-771. doi: 10.1126/science.aag2638

Klarenbeek, P., van Oostenbrugge, R. J., Lodder, J., Rouhl, R. P., Knottnerus, I. L., and Staals, J. (2013). Higher ambulatory blood pressure relates to enlarged Virchow-Robin spaces in first-ever lacunar stroke patients. J. Neurol. 260, 115-121. doi: 10.1007/s00415-012-6598-Z

Koistinaho, M., Lin, S., Wu, X., Esterman, M., Koger, D., Hanson, J., et al. (2004). Apolipoprotein E promotes astrocyte colocalization and degradation of deposited amyloid-beta peptides. Nat. Med. 10, 719-726. doi: 10.1038/nm1058

Kotter, M. R., Li, W. W., Zhao, C., and Franklin, R. J. (2006). Myelin impairs CNS remyelination by inhibiting oligodendrocyte precursor cell differentiation. J. Neurosci. 26, 328-332. doi: 10.1523/JNEUROSCI.2615-05.2006

Krasemann, S., Madore, C., Cialic, R., Baufeld, C., Calcagno, N., El Fatimy, R., et al. (2017). The TREM2-APOE pathway drives the transcriptional phenotype of dysfunctional microglia in neurodegenerative diseases. Immunity 47, 566-581.e9. doi: 10.1016/j.immuni.2017.08.008

Küppers, E., Gleiser, C., Brito, V., Wachter, B., Pauly, T., Hirt, B., et al. (2008). AQP4 expression in striatal primary cultures is regulated by dopamineImplications for proliferation of astrocytes. Eur. J. Neurosci. 28, 2173-2182. doi: 10.1111/j.1460-9568.2008.06531.x

Kwee, R. M., and Kwee, T. C. (2007). Virchow-Robin spaces at MR imaging. Radiographics 27, 1071-1086. doi: 10.1148/rg.274065722

Laitinen, L. V., Chudy, D., Tengvar, M., Hariz, M. I., and Bergenheim, A. T. (2000). Dilated perivascular spaces in the putamen and pallidum in patients with Parkinson's disease scheduled for pallidotomy: a comparison between MRI findings and clinical symptoms and signs. Mov. Disord. 15, 1139-1144. doi: 10.1002/1531-8257(200011)15:6<1139::AID-MDS1012>3.0.CO;2-E

Lee, D., Hong, I. K., and Ahn, T. B. (2015a). Dilated Virchow-Robin Space and Dopamine Transporter Imaging in the Striatum of Patients with Parkinsonism. Can. J. Neurol. Sci. 42, 248-254. doi: 10.1017/cjn.2015.43

Lee, M. S., Lyoo, C. H., and Chung, T. S. (2015b). Parkinsonism and dementia associated with giant virchow-robin spaces. J. Mov. Disord. 8, 106-107. doi: 10.14802/jmd.15013

Louveau, A., Herz, J., Alme, M. N., Salvador, A. F., Dong, M. Q., Viar, K. E., et al. (2018). CNS lymphatic drainage and neuroinflammation are regulated by meningeal lymphatic vasculature. Nat. Neurosci. 21, 1380-1391. doi: 10.1038/s41593-018-0227-9

Mancardi, G. L., Romagnoli, P., Tassinari, T., Gandolfo, C., Primavera, A., and Loeb C. (1998). Lacunae and cribriform cavities of the brain. Correlations with pseudobulbar palsy and parkinsonism. Eur. Neurol. 28, 11-17. doi: 10.1159/000116220

Martinez-Ramirez, S., Pontes-Neto, O. M., Dumas, A. P., Auriel, E., Halpin, A., Quimby, M., et al. (2013). Topography of dilated perivascular spaces in subjects from a memory clinic cohort. Neurology 80, 1551-1556. doi: 10.1212/WNL.0b013e31828f1876

Matsumoto, Y., Ohmori, K., and Fujiwara M. (1992). Microglial and astroglial reactions to inflammatory lesions of experimental autoimmune encephalomyelitis in the rat central nervous system. J. Neuroimmunol. 37, 23-33. doi: 10.1016/0165-5728(92)90152-B

McConnell, H. L., Kersch, C. N., Woltjer, R. L., and Neuwelt, E. A. (2017). The Translational Significance of the Neurovascular Unit. J. Biol. Chem. 292, 762-770. doi: $10.1074 /$ jbc.R116.760215
Mehta, S. H., Nichols, F. T 3rd, Espay, A. J., Duker, A. P., Morgan, J. C., and Sethi, K. D. (2013). Dilated Virchow-Robin Spaces and Parkinsonism. Mov. Disord. 28, 589-590. doi: 10.1002/mds. 25474

Mestre, H., Kostrikov, S., Mehta, R. I., and Nedergaard M. (2017). Perivascular spaces, glymphatic dysfunction, and small vessel disease. Clin. Sci. 131, 2257-2274. doi: 10.1042/CS20160381

Mestre, T. A., Armstrong, M. J., Walsh, R., Al Dakheel, A., Moro, E., Stoessl, A. J., et al. (2014). Can isolated enlarged virchow-robin spaces influence the clinical manifestations of parkinson's disease? Mov. Disord. Clin. Pract. 1, 67-69. doi: 10.1002/mdc3.12009

Miron, V. E. (2017). Microglia-driven regulation of oligodendrocytelineage cells, myelination, and remyelination. J. Leukoc Biol. 101, 1103-1108. doi: 10.1189/jlb.3RI1116-494R

Mosser, D. M., and Edwards, J. P. (2008). Exploring the full spectrum of macrophage activation. Nat. Rev. Immunol. 8, 958-969. doi: 10.1038/ nri2448

Moyon S Dubessy, A. L., Aigrot, M. S., Trotter, M., Huang, J. K., Dauphinot, L., Potier, M. C., et al. (2015). Demyelination causes adult CNS progenitors to revert to an immature state and express immune cues that support their migration. J. Neurosci. 35:4-20. doi: 10.1523/JNEUROSCI.084914.2015

Muoio, V., Persson, P. B., and Sendeski, M. M. (2014). The neurovascular unit concept review. Acta Physiol. 210, 790-798. doi: 10.1111/apha.12250

Mutlu, U., Adams, H. H., Hofman, A., Lugt, Av., Klaver, C. C., Vernooij, M. W., et al. (2016). Retinal microvascular calibers are associated with enlarged perivascular spaces in the brain. Stroke 47, 1374-1376. doi: 10.1161/STROKEAHA.115.012438

Nedergaard, M. (2013). Neuroscience. Garbage truck of the brain. Science 340, 1529-1530. doi: 10.1126/science.1240514

Nielsen, S., Nagelhus, E. A., Amiry-Moghaddam, M., Bourque, C., Agre, P., and Ottersen, O. P. (1997). Specialized membrane domains for water transport in glial cells: high-resolution immunogold cytochemistry of aquaporin4 in rat brain. J. Neurosci. 17, 171-180. doi: 10.1523/JNEUROSCI.17-0100171.1997

Omari, K. M., John, G. R., Sealfon, S. C., and Raine, C. S. (2005). CXC chemokine receptors on human oligodendrocytes: implications for multiple sclerosis. Brain 128, 1003-1015. doi: 10.1093/brain/awh479

Osborn, A. G., and Preece, M. T. (2006). Intracranial cysts: radiologicpathologic correlation and imaging approach. Radiology 239, 650-664. doi: 10.1148/radiol.2393050823

Park, Y. W., Shin, N. Y., Chung, S. J., Kim, J., Lim, S. M., Lee, P. H., et al. (2019). Magnetic resonance imaging-visible perivascular spaces in basal ganglia predict cognitive decline in parkinson's disease. Mov. Disord. 34, 1672-1679. doi: $10.1002 / \mathrm{mds} .27798$

Parnetti, L., Paciotti, S., Farotti, L., Bellomo, G., Sepe, F. N., and Eusebi P. (2019). Parkinson's and Lewy body dementia CSF biomarkers. Clin. Chim. Acta. 495, 318-325. doi: 10.1016/j.cca.2019. 04.078

Patankar, T. F., Mitra, D., Varma, A., Snowden, J., Neary, D., and Jackson A. (2005). Dilatation of the VirchowRobin space is a sensitive indicator of cerebral microvascular disease: study in elderly patients with dementia. AJNR Am. J. Neuroradiol. 26, 1512-1520.

Plog, B. A., and Nedergaard, M. (2018). The glymphatic system in CNS health and disease: past, present and future. Annu. Rev. Pathol. 13, 379-394. doi: 10.1146/annurev-pathol-051217111018

Pollock, H., Hutchings, M., Weller, R. O., and Zhang, E. T. (1997). Perivascular spaces in the basal ganglia of the human brain: their relationship to lacunes. J. Annat. 191, 337-346. doi: 10.1046/j.1469-7580.1997.191 30337.x

Ponomarev, E. D., Shriver, L. P., Maresz, K., Dittel, B. N. (2005). Microglial cell activation and proliferation precedes the onset of CNS autoimmunity. J. Neurosci. Res. 81, 374-389. doi: 10.1002/jnr. 20488

Potter, G. M., Chappell, F. M., Morris, Z., and Wardlaw, J. M. (2015). Cerebral perivascular spaces visible on magnetic resonance imaging: development of a qualitative rating scale and its observer reliability. Cerebrovasc. Dis. 39, 224-231. doi: 10.1159/000375153 
Presta, I., Vismara, M., Novellino, F., Donato, A., Zaffino, P., Scali, E., et al. (2018). Innate immunity cells and the neurovascular unit. Int. J. Mol. Sci. 19:3856. doi: 10.3390/ijms19123856

Ramirez, J., Berezuk, C., McNeely, A. A., Gao, F., McLaurin, J., Black, S. E. (2016). Imaging the Perivascular Space as a Potential Biomarker of Neurovascular and Neurodegenerative Diseases. Cell Mol. Neurobiol. 36, 289-299. doi: 10.1007/s10571-016-0343-6

Ramirez, J., Berezuk, C., McNeely, A. A., Scott, C. J., Gao, F., and Black, S. E. (2015). Visible Virchow-Robin spaces on magnetic resonance imaging of Alzheimer's disease patients and normal elderly from the Sunnybrook Dementia Study. J. Alzheimers Dis. 43, 415-424. doi: 10.3233/JAD132528

Reed-Geaghan, E. G., Savage, J. C., Hise, A. G. and Landreth, G. E. (2009). CD14 and Toll-like receptors 2 and 4 are required for fibrillar A $\beta$-stimulated microglial activation. J. Neurosci. 29, 11982-11992. doi: 10.1523/JNEUROSCI.3158-09.2009

Ringstad, G., Vatnehol, S. A. S., and Eide, P. K. (2017). Glymphatic MRI in idiopathic normal pressure hydrocephalus. Brain 140, 2691-2705. doi: 10.1093/brain/awx191

Roher, A. E., Kuo, Y. M., Esh, C., Knebel, C., Weiss, N., Kalback, W., et al. (2003). Cortical and leptomeningeal cerebrovascular amyloid and white matter pathology in Alzheimer's disease. Mol. Med. 9, 112-122. doi: 10.1007/BF03402043

Rouhl, R. P., van Oostenbrugge, R. J., Knottnerus, I. L., Staals, J. E., and Lodder, J. (2008). Virchow-Robin spaces relate to cerebral small vessel disease severity. J. Neurol. 255, 692-696. doi: 10.1007/s00415-008-0777-y

Satizabal, C. L., Zhu, Y. C., Mazoyer, B., Dufouil, C., and Tzourio C. (2012). Circulating IL-6 and CRP are associated with MRI findings in the elderly: the 3C-Dijon Study. Neurology 8, 720-727. doi: 10.1212/WNL.0b013e3182 $48 \mathrm{e} 50 \mathrm{f}$

Schain, A. J., Melo-Carrillo, A., Strassman, A. M., and Burstein R. (2017). Cortical spreading depression closes paravascular space and impairs glymphatic flow: implications for migraine headache. J. Neurosci. 37, 2904-2915. doi: 10.1523/JNEUROSCI.3390-16.2017

Sengillo, J. D., Winkler, E. A., Walker, C. T., Sullivan, J. S., Johnson, M., Zlokovic, B. V. (2013). Deficiency in mural vascular cells coincides with bloodbrain barrier disruption in Alzheimer's disease. Brain Pathol. 23, 303-310. doi: 10.1111/bpa.12004

Shams, S., Martola, J., Charidimou, A., Larvie, M., Granberg, T., Shams, M., et al. (2017). Topography and Determinants of Magnetic Resonance Imaging (MRI)- visible perivascular spacesin a large memory clinic cohort. J. Am. Heart Assoc. 6:e006279. doi: 10.1161/JAHA.117. 006279

Shibata, K., Sugiura, M., Nishimura, Y., and Sakura H. (2019). The effect of small vessel disease on motor and cognitive function in Parkinson's disease. Clin. Neurol. Neurosurg. 182, 58-62. doi: 10.1016/j.clineuro.2019. 04.029

Simon, M. J., and Iliff, J. J. (2016). Regulation of cerebrospinal fluid (CSF) flow in neurodegenerative, neurovascular and neuroinflammatory disease. Biochim. Biophys. Acta. 1862, 442-451. doi: 10.1016/j.bbadis.2015. 10.014

Sosunov, A. A., Wu, X., Tsankova, N. M., Guilfoyle, E., McKhann, G. M. 2nd., and Goldman, J. E. (2014). Phenotypic heterogeneity and plasticity of isocortical and hippocampal astrocytes in the human brain. J. Neurosci. 34, 2285-2298. doi: 10.1523/JNEUROSCI.4037-13.2014

Spencer, J. I., Bell, J. S., and DeLuca, G. C. (2018). Vascular pathology in multiple sclerosis: reframing pathogenesis around the blood-brain barrier. J. Neurol. Neurosurg. Psychiatry 89, 42-52. doi: 10.1136/jnnp-2017-3 16011

Stamatovic, S. M., Johnson, A. M., Keep, R. F., and Andjelkovic, A. V. (2016). Junctional proteins of the blood-brain barrier: New insights into function and dysfunction. Tissue Barriers 4:e1154641. doi: 10.1080/21688370.2016.1 154641

Sundaram, S., Hughes, R. L., Peterson, E., Müller-Oehring, E. M., Brontë-Stewart, H. M., Poston, K. L., et al. (2019). Establishing a framework for neuropathological correlates and glymphatic system functioning in Parkinson's disease. Neurosci. Biobehav. Rev. 103, 305-315. doi: 10.1016/j.neubiorev.2019.05.016
Sweeney, M. D., Kisler, K., Montagne, A., Toga, A. W., and Zlokovic, B. V. (2018). The role of brain vasculature in neurodegenerative disorders. Nat. Neurosci. 21, 1318-1331. doi: 10.1038/s41593-018-0234-x

Tarasoff-Conway, J. M., Carare, R. O., Osorio, R. S., Glodzik, L., Butler, T., Fieremans, E., et al. (2015). Clearance systems in the brainimplications for Alzheimer disease. Nat. Rev. Neurol. 11, 457-470. doi: 10.1038/nrneurol.2015.119

Thore, C. R., Anstrom, J. A., Moody, D. M., Challa, V. R., Marion, M. C., and Brown, W. R. (2007). Morphometric analysis of arteriolar tortuosity in human cerebral white matter of preterm, young, and aged subjects. J. Neuropathol. Exp. Neurol. 66, 337-345. doi: 10.1097/nen.0b013e3180537147

Trevaskis, N. L., Kaminskas, L. M., and Porter, C. J. (2015). From sewer to saviour - targeting the lymphatic system to promote drug exposure and activity. Nat. Rev. Drug. Discov. 14, 781-803. doi: 10.1038/nrd4608

Uemura, M. T., Ihara, M., Maki, T., Nakagomi, T., Kaji, S., Uemura, K., et al. (2018). Pericyte-derived bone morphogenetic protein 4 underlies white matter damage after chronic hypoperfusion. Brain Pathol. 28, 521-535. doi: 10.1111/bpa.12523

van Veluw, S. J., Biessels, G. J., Bouvy, W. H., Spliet, W. G., Zwanenburg, J. J., Luijten, P. R., et al. (2016). Cerebral amyloid angiopathy severity is linked to dilation of juxtacortical perivascular spaces. J. Cereb. Blood Flow Metab. 36, 576-580. doi: 10.1177/0271678X15620434

van Zwam, M., Huizinga, R., Melief, M. J., Wierenga-Wolf, A. F., van Meurs, M., Voerman, J. S., et al. (2009). Brain antigens in functionally distinct antigenpresenting cell populations in cervical lymph nodes in MS and EAE. J. Mol. Med. 87, 273-286. doi: 10.1007/s00109-008-0421-4

Verkhratsky, A., and Steinhäuser, C. (2000). Ion channels in glial cells. Brain Res Brain Res Rev. 32, 380-412. doi: 10.1016/S0165-0173(99)00093-4

Wakita, H., Tomimoto, H., Akiguchi, I., Kimura, J. (1994). Glial activation and white matter changes in the rat brain induced by chronic cerebral hypoperfusion: an immunohistochemical study. Acta Neuropathol. 87, 484-492. doi: 10.1007/BF00294175

Wan, Y., Hu, W., Gan, J., Song, L., Wu, N., Chen, Y., et al. (2019). Exploring the association between Cerebral small-vessel diseases and motor symptoms in Parkinson's disease. Brain Behav. 9:e01219. doi: 10.1002/brb 3.1219

Wardlaw, J. M., Smith, C., and Dichgans, M. (2013). Mechanisms of sporadic cerebral small vessel disease: insights from neuroimaging. Lancet Neurol. 12, 483-497. doi: 10.1016/S1474-4422(13)70060-7

Weller, R. O., Hawkes, C. A., Kalaria, R. N., Werring, D. J., and Carare, R. O. (2015). White matter changes in dementia: role of impaired drainage of interstitial fluid. Brain Pathol. 25, 63-78. doi: 10.1111/bpa.12218

Weller, R. O., Subash, M., Preston, S. D., Mazanti, I., and Carare, R. O. (2008). Perivascular drainage of amyloid-beta peptides from the brain and its failure in cerebral amyloid angiopathy and Alzheimer's disease. Brain Pathol. 18, 253-266. doi: 10.1111/j.1750-3639.2008.00133.x

Wilhelm, I., Nyúl-Tóth, Á., Suciu, M., Hermenean, A., and Krizbai, I. A. (2016). Heterogeneity of the blood-brain barrier. Tissue Barriers. 4:e1143544. doi: 10.1080/21688370.2016.1143544

Wolburg-Buchholz, K., Mack, A. F., Steiner, E., Pfeiffer, F., Engelhardt, B., and Wolburg H. (2009). Loss of astrocyte polarity marks blood-brain barrier impairment during experimental autoimmune encephalomyelitis. Acta Neuropathol. 118, 219-233. doi: 10.1007/s00401-009-0558-4

Wolvers, D. A., Coenen-de Roo, C. J., Mebius, R. E., van der Cammen, M. J., Tirion, F., Miltenburg, A. M., et al. (1999). Intranasally induced immunological tolerance is determined by characteristics of the draining lymph nodes: studies with OVA and human cartilage gp-39. J. Immunol. 162, 1994-1998.

Wong, A. D., Ye, M., Levy, A. F., Rothstein, J. D., Bergles, D. E., and Searson, P. C. (2013). The blood-brain barrier: an engineering perspective. Front. Neuroeng. 6:7. doi: 10.3389/fneng.2013.00007

Wuerfel, J., Haertle, M., Waiczies, H., Tysiak, E., Bechmann, I., Wernecke, K. D., et al. (2008). Perivascular spaces-MRI marker of inflammatory activity in the brain? Brain 131, 2332-2340. doi: 10.1093/brain/awn171

Xie, L., Kang, H., Xu, Q., Chen, M. J., Liao, Y., Thiyagarajan, M., et al. (2013). Sleep drives metabolite clearance from the adult brain. Science 342, 373-377. doi: $10.1126 /$ science. 1241224

Yang, F., Li, W. J., and Huang, X. S. (2018). Alpha-synuclein levels in patients with multiple system atrophy: a meta-analysis. Int. J. Neurosci. 128, 477-486. doi: 10.1080/00207454.2017.1394851 
Yang, W., Wu, Q., Yuan, C., Gao, J., Xiao, M., Gu, M., et al. (2012). Aquaporin4 mediates astrocyte response to $\beta$-amyloid. Mol. Cell. Neurosci. 49, 406-414. doi: 10.1016/j.mcn.2012.02.002

Zhang, J., Yang, B., Sun, H., Zhou, Y., Liu, M., Ding, J., et al. (2016). Aquaporin-4 deficiency diminishes the differential degeneration of midbrain dopaminergic neurons in experimental parkinson's disease. Neurosci. Lett. 614, 7-15. doi: 10.1016/j.neulet.2015.12.057

Zhu, Y. C., Tzourio, C., Soumare, A., Mazoyer, B., Dufouil, C., and Chabriat H. (2010). Severity of dilated VirchowRobin spaces is associated with age, blood pressure, and MRI markers of small vessel disease: a populationbased study. Stroke 41, 2483-2490. doi: 10.1161/STROKEAHA.110.5 91586
Conflict of Interest: The authors declare that the research was conducted in the absence of any commercial or financial relationships that could be construed as a potential conflict of interest.

Copyright $\odot 2020$ Troili, Cipollini, Moci, Morena, Palotai, Rinaldi, Romano, Ristori, Giubilei, Salvetti, Orzi, Guttmann and Cavallari. This is an open-access article distributed under the terms of the Creative Commons Attribution License (CC BY). The use, distribution or reproduction in other forums is permitted, provided the original author(s) and the copyright owner(s) are credited and that the original publication in this journal is cited, in accordance with accepted academic practice. No use, distribution or reproduction is permitted which does not comply with these terms. 